\title{
Stereoselective Synthesis of $\delta$-Lactones from 5-Oxoalkanals via One-Pot Sequential Acetalization, Tishchenko Reaction, and Lactonization by Cooperative Catalysis of Samarium Ion and Mercaptan
}

\author{
J ue-Liang Hsu and J im-Min Fang* \\ Department of Chemistry, National Taiwan University, Taipei, Taiwan 106, Republic of China \\ jmfang@ccms.ntu.edu.tw
}

Received August 25, 2001

\begin{abstract}
By the synergistic catalysis of samarium ion and mercaptan, a series of 5-oxoalkanals was converted to (substituted) $\delta$-lactones in efficient and ster eosel ective manners. This one-pot procedure comprises a sequence of acetalization, Tishchenko reaction and lactonization. The deliberative use of mercaptan, by comparison with al cohol, is advantageous to facilitate the catalytic cycle. The reaction mechanism and stereochemistry are proposed and supported by some experimental evidence. Such samarium ion/mercaptan cocatalyzed reactions show the feature of remote control, which is applicable to the asymmetric synthesis of optically active $\delta$-lactones. This study al so demonstrates the synthesis of two insect pheromones, $(2 S, 5 R)$-2-methylhexanolide and (R)-hexadecanolide, as examples of a new protocol for asymmetric reduction of long-chain aliphatic ketones.
\end{abstract}

\section{Introduction}

Lanthanoid reagents have been widely utilized in organic synthesis. ${ }^{1} \mathrm{Sml}_{2}$ can function as a one-electron reducing agent, ${ }^{2}$ and both $\mathrm{Sml}_{2}$ and $\mathrm{Sml}_{3}$ can function as Lewis acids to promote a variety of reactions, such as aldol reactions, ${ }^{3}$ Diels-Alder reactions, ${ }^{4}$ Meerwein reductions, ${ }^{5}$ oxirane rearrangements, ${ }^{6}$ Tishchenko reactions, ${ }^{3 \mathrm{~b}, 7}$ and sequential aldol-acetalization-Tishchenko reactions. . $^{3,7}$ Uenishi and co-workers ${ }^{8}$ have demonstrated that 5-oxo4-silyloxyhexanals can undergo the intramolecular Tish-

(1) (a) Molander, G. A. I n Comprehensive Organic Synthesis; Trost, B. M.; Fleming, I., Eds.; Pergamon Press: Oxford, 1991; Vol. 1, pp 251282. (b) Molander, G. A. Chem. Rev. 1992, 92, 29. (c) I mamoto, T. Lanthanides in Organic Synthesis; Academic Press: London, 1994.

(2) Reviews of the reactions of Sml 2 : (a) Kagan, H. B.; Namy, J. L. Tetrahedron 1986, 42, 6573. (b) Inanaga, J . J . Synth. Org. Chem. 1989, 47, 200. (c) Soderquist, J. A. Aldrichim. Acta 1991, 24, 15. (d) Brandukova, N. E.; Vygodskii, Y. S.; Vinogradova, S. V. Russ. Chem. Rev. 1994, 63, 345. (e) Molander, G. A.; Harris, C. R. Chem. Rev. 1996, 96, 307. (f) Molander, G. A.; Harris, C. R. Tetrahedron 1998, 54, 3321.

(3) (a) Van de Weghe, P.; Collin, J . Tetrahedron Lett. 1993, 34, 3881 (b) Chuang, T.-H.; Fang, J .-M.;J iaang, W.-T.; Tsai, Y.-M.J . Org. Chem. 1996, 61, 1794. (c) Lu, L.; Chang, H.-Y.; Fang, J.-M. J. Org. Chem. 1999, 64, 843.

(4) Van de Weghe, P.; Collin, J . Tetrahedron Lett. 1994, 35, 2545.

(5) (a) Evans, D. A.; Nelson, S. G.; Gagne, M. R.; Muci, A. R. J . Am. Chem. Soc. 1993, 115, 9800. (b) Ding, Z.-B.; Wu, S.-H. HuaxueXuebao 1997, 55, 351. (c) Ding, Z.-B.; Cheng, K.-J .; Wu, S.-H. HuaxueXuebao $1997,55,1030$

(6) Prandi, J .; Namy, J . L.; Menoret, G.; Kagan, H. B. J . Organomet. Chem. 1985, 285, 449 .

(7) (a) Collin, J .; Namy, J . L.; Kagan, H. B. Nouv. J . Chem. 1986 10, 229. (b) Evans, D. A.; Hoveyda, A. H. J . Am. Chem. Soc. 1990 112, 6447. (c) Curran, D. P.; Wolin, R. L. Synlett 1991, 317. (d) Horiuchi, Y.; Taniguchi, M.; Oshima, K.; Utimoto, K. Tetrahedron Lett. 1995, 36, 5353. Examples of sequential aldol-acetalization-Tishchenko reactions using the promoters other than samarium ions: (e) Burkhardt, E. R.; Bergman, R. G.; Heathcock, C. H. Organometallics 1990, 9, 30 . (f) Baramee, A.; Chaichit, N.; Intawee, P.; Thebtaranonth, C.: Thebtaranonth, Y.J . Chem. Soc., Chem. Commun. 1991, 1016. (g) Mahrwald R.; Costisella, G. Synthesis 1996, 1087. (h) Bodnar, P. M.; Shaw, J . T.; Woerpel, K. A. J . Org. Chem. 1997, 62, 5674. (i) Mascarenhas, C. M.; Miller, S. P.; White, P. S.; Morken, J . P. Angew. Chem., Int. Ed. 2001 40,601 .

(8) Uenishi, J .; Masuda, S.; Wakabayashi, S. Tetrahedron Lett. 1991, $32,5097$. chenko oxidoreductions on treatment with stoichiometric amounts of (t-BuO)Sml ${ }_{2}$ or aged $\mathrm{Sml}_{2}$ sol ution (presumably containing $\mathrm{Sm}^{3+}$ ion), followed by in situ cyclizations, to give the corresponding $\delta$-lactones. They al so indicate that the silyloxy substituent is essential for such transformation. Otherwise, an unsubstituted substrate like 5 -oxohexanal affords only a low yield ( $10 \%)$ of $\delta$-methyl$\delta$-lactone on treatment with (t-BuO)Sml ${ }_{2}$, or simply the pinacolic coupling product on treatment with freshly prepared $\mathrm{Sml}_{2}$ solution. Iadonisi and co-workers ${ }^{9}$ have employed (t-BuO)Sml 2 (2.5 equiv) to promote the Tishchenko reactions of hexos-5-uloses to give the tert-butyl esters of aldonic acids, which were subsequently converted into the corresponding sugar lactones. By using stoichiometric amounts of $\mathrm{Sml}_{2}$ as the Lewis acid promoter, we have converted 5-trimethylsilyl-5-oxopentanal to $\delta$-trimethylsilyl- $\delta$-lactone in the presence of $\mathrm{MeOH}$ (Figure 1).3b

The above-mentioned reactions $\mathrm{s}^{3 \mathrm{~b}, 8,9}$ are presumably initiated by addition of $\mathrm{ROH}$ (or $\mathrm{RO}^{-}$) to the aldehyde group to form a hemiacetal with the assistance of samarium ion as depicted in Figure 1. An intramolecular hydride transfer to the ketone group (Tishchenko reaction) occurs via a rigid chelate transition state. ${ }^{3 c, 7}$ The $\delta$-oxyester intermediate can proceed with an in situ cyclization in appropriate cases to give the observed $\delta$-lactone product. Along this line, we considered that using mercaptan RSH to replace alcohol $\mathrm{ROH}$ would be advantageous. RSH would be a better nucleophile than $\mathrm{ROH}$ on addition to the aldehyde group of 5-oxopentanals, and the resulting thioester intermediates would also be more reactive than esters in the subsequent lactonizations. We thus set out a detailed study of such onepot sequential acetalization, Tishchenko reaction, and lactonization by the promotion of samarium ions and mercaptans. The effects of substrates, nucleophiles,

(9) Adinolfi, M.; Barone, G.; De Lorenzo, F.; Iadonisi, A. Synlett 1999, 


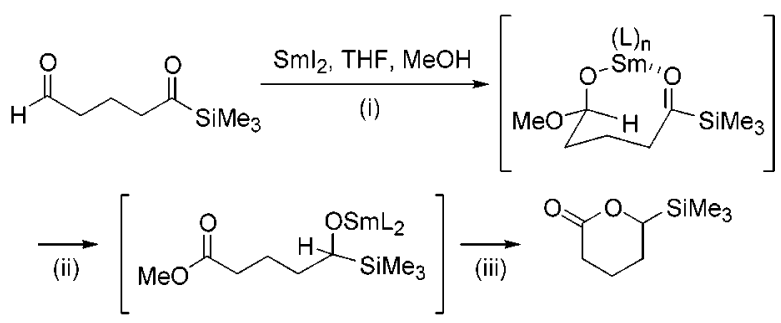

Figure 1. Samarium ion promoted formation of $\delta$-lactone from 5-oxo-5-silylpentanal: (i) acetalization, (ii) Tishchenko reaction, and (iii) lactonization.

catalysts, and reaction conditions would be examined. In a preliminary report, ${ }^{10}$ we have utilized $\mathrm{Sml}_{2}$ and 2-propanethiol (i-PrSH) as the combined catalysts to convert 5 -oxopentanals into their corresponding $\delta$-lactones. (eq 1). Our ultimate goal is to devise a catalytic method for

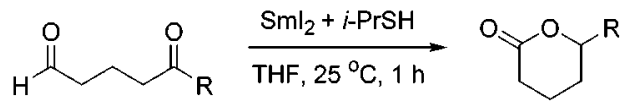

the synthesis of optically active $\delta$-lactones, which often occur in nature or as parts of natural products. ${ }^{11}$

\section{Results and Discussion}

Preparations and Reactions of 5-0xoalkanals. A series of 5-oxoalkanals $\mathbf{1 a}-\mathbf{g}$ and $\mathbf{1 j}-\mathbf{m}$ were prepared from cyclopentanone by a three-step sequence ${ }^{12}$ (Scheme 1): (i) addition of Grignard reagents, (ii) dehydration, and (iii) ozonolysis. 6,6-Dimethyl-5-oxoheptanal (1h) was prepared by alkylation of the $\mathrm{N}, \mathrm{N}$-dimethylhydrazone of 3,3-dimethyl-2-butanone, followed by ozonolysis. ${ }^{13}$ Alternatively, the silyl enol ether of isobutyraldehyde underwent a Michael addition with methyl vinyl ketone to give 2,2-dimethyl-5-oxohexanal (1i). ${ }^{14}$ We found that this reaction was facilitated by using $\mathrm{BF}_{3} \cdot \mathrm{OEt}_{2}$ as the promoter in addition to $\mathrm{Al}_{2} \mathrm{O}_{3}-\mathrm{ZnCl}_{2}$.

Using 5-oxo-5-phenylpentanal (1a) as a model substrate, its reactions with $\mathrm{Sml}_{2}$ in the presence of $\mathrm{i}-\mathrm{PrOH}$ or i-PrSH were investigated (Table 1). In the presence of $50 \mathrm{~mol} \%$ of $\mathrm{Sml}_{2}$ and $50 \mathrm{~mol} \%$ of $\mathrm{i}-\mathrm{PrOH}$, the tandem acetalization-Tishchenko reaction gave a $36 \%$ yield of isopropyl 5-hydroxy-5-phenyl pentanoate. The subsequent lactonization did not occur under such reaction conditions $\left(25^{\circ} \mathrm{C}, 30 \mathrm{~min}\right)$. However, a dramatic increase of the $\delta$-lactone product 2 a $(53 \%$ yield) was obtained when i-PrSH was introduced to the reaction media (entry 2 , Table 1). Moreover, a quantitative yield of lactone $\mathbf{2 a}$ was procured when la was stirred with $\mathrm{Sml}_{2}(50 \mathrm{~mol} \%)$ and

(10) Hsu, J .-L.; Chen, C.-T.; Fang, J .-M. Org. Lett. 1999, 1, 1989

(11) (a) Ohl off, G. Fortschr. Chem. Org. Naturst. 1978, 35, 431. (b) Mulzer, I . In Compr. Org. Funct. Group Transform; Katrizky, A. R. Meth-Cohn, O.; Rees, C. W., Eds.; Elsevier: Oxford, 1995; Vol. 5, 121179. (c) Ley, S. V.; Cox, L. R.; Meek, G. Chem. Rev. 1996, 96, 423. (d) Collins, I.; J. Chem. Soc., Perkin Trans. 1 1998, 1869. Mcrae, K. J. Rizzacasa, M. A. J . Org. Chem. 1997, 62, 1196. Urabe, H.; Matsuka, T.; Sato, F. Tetrahedron Lett. 1992, 33, 4183.

(12) (a) Garbish, E. W., J r. J . Org. Chem. 1961, 26, 4165. (b) Hon, Y.-S.; Lin, S.-W.: Lu, L.; Chen, Y.-J . Tetrahedron 1995, 51, 5019.

(13) (a) Corey, E. J .; Enders, D. Tetrahedron Lett. 1976, 17, 3. (b) Corey, E. J .; Enders, D. Chem. Ber. 1978, 111, 1362. (c) Molander, G. A.; Cameron, K. O. J. Am. Chem. Soc. 1993, 115, 830.

(14) (a) Amice, P.; Blanco, L.; Conia, J . M. Synthesis 1976, 197. (b) Ranu, B. C.; Saha, M.; Bhar, S. J . Chem. Soc., Perkin Trans. 11985 2701. (c) Ranu, B. C.; Saha, M.; Bhar, S. Tetrahedron Lett. 1993, 34 1989.
Scheme 1. Preparation of 5-Oxoalkanals la-m

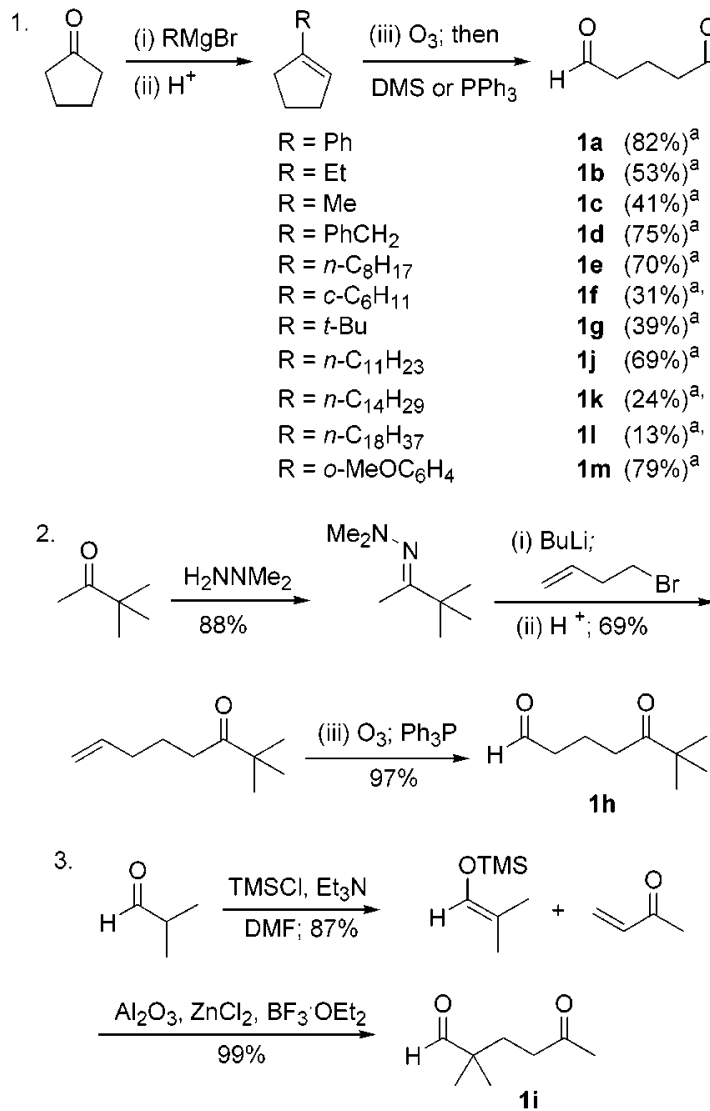

(a) The overall yield of three steps. (b) The yield of $\mathbf{1 f}$ was low because the dehydration step also gave a side product of benzylidenecyclopentane. (c) Because the alkene precursors were partially soluble in $\mathrm{CH}_{2} \mathrm{Cl}_{2}$ on ozonolysis, significant amounts of alkenes were also recovered.

Table 1. Reactions of 5-0xo-5-phenylpentanal (1a) Promoted by $\mathrm{Sml}_{2}$ in the Presence of i-PrSH or i-PrOH (THF, $25^{\circ} \mathrm{C}, 30 \mathrm{~min}$ )

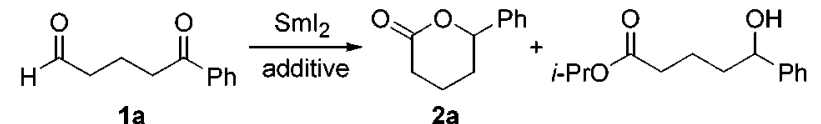

\begin{tabular}{cccc}
\hline entry & mol \% of Sml 2 & additive (mol \%) & yield (\%) of 2a \\
\hline 1 & 50 & i-PrOH (50) & a \\
2 & 50 & i-PrOH (50) & $53^{\mathrm{b}, \mathrm{c}}$ \\
3 & 50 & i-PrSH (50) & \\
4 & 20 & i-PrSH (40) & $99^{\mathrm{b}}$ \\
5 & 10 & i-PrSH (10) & $100^{\mathrm{b}}$ \\
6 & 10 & i-PrSH (20) & $27^{\mathrm{b}}$ \\
& & i-PrSH (5) & 0
\end{tabular}

a This reaction gave $36 \%$ yield of isopropyl 5-hydroxy-5-phenylpentanoate. ${ }^{b}$ The yield was estimated by ${ }^{1} \mathrm{H}$ NMR analysis of the

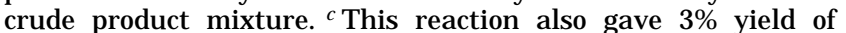
isopropyl 5-hydroxy-5-phenylpentanoate.

i-PrSH (40 mol \%) at room temperature for 30 min (entry 3, Table 1).

A quantitative yield of lactone $\mathbf{2 a}$ was also obtained by using smaller amounts of promoters, $20 \mathrm{~mol} \%$ of $\mathrm{Sml}_{2}$, and $10 \mathrm{~mol} \%$ of i-PrSH (entry 4, Table 1). The representative procedure is described in the Experimental Section (method D). No aldol or pinacol products were observed in such reaction conditions. However, using 10 $\mathrm{mol} \%$ of $\mathrm{Sml}_{2}$ only provided a low yield of the desired product (entries 5 and 6, Table 1). Sml 2 or i-PrSH alone did not promote the formation of lactone $\mathbf{2 a}$. 
Scheme 2. Conversion of 5-Alkyl- and 5-Phenyl-5-oxopentanals to $\delta$-Lactones by Using the Premixing and Reinjection Procedure

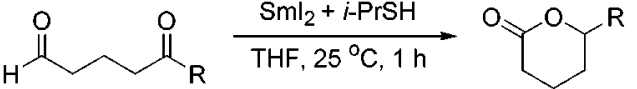

$$
\begin{aligned}
& \text { 1a } \mathrm{R}=\mathrm{Ph} \quad \text { 2a }(99 \%) \\
& \text { 1b } \mathbf{R}=\mathrm{Me} \quad \text { 2b }(99 \%) \\
& \text { 1c } \mathrm{R}=\mathrm{Et} \quad \text { 2c }(91 \%) \\
& \text { 1d } \mathrm{R}=n-\mathrm{C}_{6} \mathrm{H}_{13} \quad \text { 2d }(99 \%) \\
& \text { 1e } \mathrm{R}=n-\mathrm{C}_{8} \mathrm{H}_{17} \quad \text { 2e }(94 \%) \\
& \text { If } \mathrm{R}=\mathrm{PhCH}_{2} \quad \text { 2f }(99 \%) \\
& \text { 1g } \mathbf{R}=c-\mathrm{C}_{6} \mathrm{H}_{11} \quad \mathbf{2 g}(96 \%) \\
& \text { 1h } \mathrm{R}=\mathrm{t} \text {-Bu } \quad \text { 2h }(91 \%)
\end{aligned}
$$

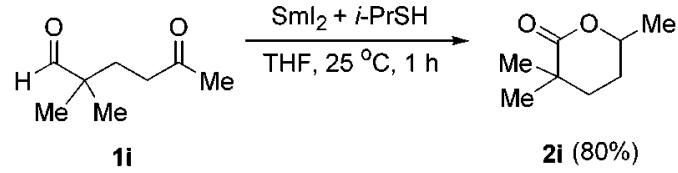

To our surprise, only a small portion $(<10 \%)$ of 5 -alkyl5-oxopentanals $\mathbf{1 b}-\mathbf{h}$ could be converted into their corresponding $\delta$-substituted- $\delta$-lactones $\mathbf{2} \mathbf{b}-\mathbf{h}$ by using the above-mentioned procedure with $\mathrm{Sml}_{2}$ and i-PrSH as the promoters. This discrepancy might be attributable to the lower reactivity of aliphatic ketones (e.g., $\mathbf{1 b}-\mathbf{h}$ ) by comparison with aromatic ketones (e.g., la). Fortunately, we found that a slightly modified procedure, premixing and re-injection (method $\mathrm{E}$ in Experimental Section), could lead to efficient formations of lactones $\mathbf{2} \mathbf{b}-\mathbf{h}$ (Scheme 2). Thus, an aliquot of Sml $2 /$ i-PrSH (1-5 mol \% in $1 \mathrm{~mL}$ of THF) was premixed with the substrate (1bh) in an oven-dried syringe. The resulting yellow solution, an indicator of trivalent samarium ion, was then added dropwise to the original $\mathrm{Sml} / \mathrm{i}-\mathrm{PrSH}$ (50/40 mol \%) solution in THF (14 mL). Accordingly, the desired lactones $\mathbf{2} \mathbf{b}-\mathbf{h}$ were obtained in excellent yields (>90\%). This modified procedure was also suitable for the transformation of aromatic ketone $\mathbf{1 a}$ into lactone $\mathbf{2 a}$. Even the sterically demanding aldehyde $\mathbf{1 i}$ was al so successfully converted to lactone $\mathbf{2 i}$ in $80 \%$ yield.

It was noted that lactone $\mathbf{2 i}$ would not be prepared by Baeyer-Villiger oxidation of 2,2,5-trimethylcyclopentanone due to the incompatible regiochemistry. ${ }^{15}$ When 5-oxotridecanal (1e) was treated with stoichiometric amounts of $\mathrm{Sml}_{2}$ and i-PrOH, both Tishchenko oxidoreduction and intramolecular pinacolic coupling occurred to give a mixture of isopropyl 5-hydroxytridecanoate and 1-octyl-1,2-cyclopentanediol in a ratio of 1:1. No lactone $\mathbf{2 e}$ was formed in the absence of mercaptan.

Reaction mechanism. On the basis of the above experimental results, one can propose a possible reaction mechanism for the formation of $\delta$-lactones (Figure 2). A Lewis acid such as the presumed (i-PrS)Sml ${ }_{2}$ or the related samarium species ${ }^{16}$ can promote the addition of i-PrSH to the aldehyde group of a 5-oxopentanal substrate. The samarium-bound hemithioacetal intermediate (A) can undergo an intramolecular hydride shift to give the intermediate of $\delta$-oxyacid thioester (B). The reaction would proceed further with an irreversible lactonization, and release the catalyst (i-PrS)Sml ${ }_{2}$ (or the related

(15) (a) Krow, G. R. Org. React. 1993, 43, 251. (b) Krow, G. R. In Comprehensive Organic Synthesis; Trost, B. M.; Fleming, I., Eds.; Pergamon Press: Oxford, 1991; Vol. 7, p 671-688.

(16) It has been reported (ref 7a) that $5 \mathrm{ml}_{2}$ reacts with alcohol $\mathrm{ROH}$ to give (RO)Sml ${ }_{2}$ in the presence of a metallic salt as the electron carrier.

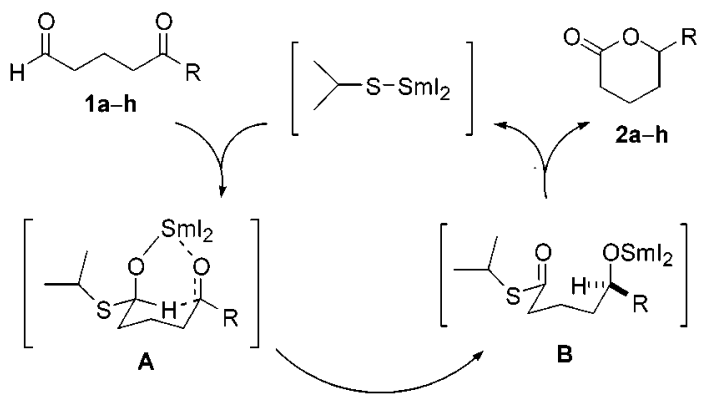

Figure 2. A proposed catalytic cycle for the formation of $\delta$-lactones.

Table 2. Transformation of 5-0xo-5-phenylpentanal (1a) and 5-Oxotridecanal ( $1 e$ ) into Lactones $2 a$ and $2 e$ by Using $\mathrm{Sml}_{2}$ and Disulfide (THF, $25^{\circ} \mathrm{C}, 1 \mathrm{~h}$ )

\begin{tabular}{cccll}
\hline entry & substrate & $\begin{array}{c}\text { mol \% } \\
\text { of Sml }\end{array}$ & $\begin{array}{c}\text { disulfide } \\
(\mathrm{mol} \%)\end{array}$ & $\begin{array}{c}\text { product } \\
\text { (yield, \%) }\end{array}$ \\
\hline 1 & $\mathbf{1 a}$ & 42 & $(\mathrm{PhS})_{2}(20)$ & $\mathbf{2 a}(100)$ \\
2 & $\mathbf{1 a}$ & 12 & $(\mathrm{PhS})_{2}(5)$ & $\mathbf{2 a}(100)$ \\
3 & $\mathbf{1 a}$ & 42 & $(\mathrm{MeS})_{2}(20)$ & $\mathbf{2 a}(67)$ \\
4 & $\mathbf{1 a}$ & 42 & $(\mathrm{i}-\mathrm{PrS})_{2}(20)$ & $\mathbf{2 a}(68)$ \\
5 & $\mathbf{1 e}$ & 42 & $(\mathrm{PhS})_{2}(20)$ & $\mathbf{2 e}(100)$ \\
6 & $\mathbf{1 e}$ & 85 & $(\mathrm{MeS})_{2}(40)$ & $\mathbf{2 e}(87)$ \\
7 & $\mathbf{1 e}$ & 42 & $(\mathrm{i}-\mathrm{PrS})_{2}(20)$ & $\mathbf{2 e}(56)$
\end{tabular}

samarium species) for the next cycle. Thedeliberativeuse of mercaptan is proved to facilitate the catalytic cycle, due to its strong nucl eophilicity toward aldehydeand thehigh aptitude of the thioester intermediate toward Iactonization.

It is known that $\mathrm{Sml}_{2}$ can cleave the $\mathrm{S}-\mathrm{S}$ bond of diphenyl disulfide. ${ }^{17}$ Indeed, by replacing $\mathrm{Sml}_{2} / \mathrm{i}-\mathrm{PhSH}$ with $\mathrm{Sml}_{2} /(\mathrm{PhS})_{2}$, the reactions of oxoalkanals $\mathbf{l a}$ and $\mathbf{l e}$ also proceeded smoothly to give lactones $\mathbf{2 a}$ and $\mathbf{2 e}$ in quantitative yields (entries 1 and 5, Table 2). When $(\mathrm{MeS})_{2}$ or (i-PrS) $)_{2}$ were used instead of $(\mathrm{PhS})_{2}$, lactones $2 \mathbf{a}$ and $\mathbf{2 e}$ were obtained in modest yields (56-87\%, entries 3, 4, 6, and 7, Table 2). This trend was consistent with the higher reactivity of diphenyl disulfide toward $\mathrm{Sml}_{2}$ than dialkyl disulfides. The combination of $\mathrm{Sml}_{3}$ (20 mol \%) and PhSLi (20 mol \%), instead of $\mathrm{Sml}_{2}$ and mercaptan, was also utilized to promote the transformation of oxopentanal $\mathbf{1 a}$ into lactone $\mathbf{2 a}$ ( $99 \%$ yield) in an expedient manner. These experiments support that the in situ generated (RS)Sml 2 or the related species actually plays a role as a reactive catalyst to facilitate the sequence of acetalization, Tishchenko reaction and lactonization. The protocol using the sol id reagent of $(\mathrm{PhS})_{2}$ to replace the odoriferous reagent i-PrSH also makes this method more attractive. A quantitative yield of lactone 2a was also achieved by using even less amounts of promoters, $\mathrm{Sml}_{2}(12 \mathrm{~mol} \%)$, and $(\mathrm{PhS})_{2}(5 \mathrm{~mol} \%$ ) (entry 2 , Table 2). By comparison, the conventional route to $\delta$-lactones often requires excess amounts of oxidizing and reducing agents to convert 5-oxoalkanals into 5-hydroxyal kanoic acid for the subsequent lactonization. From the point of atom economy, our method using catalytic amounts of samarium ion and mercaptan to effect the intramol ecular oxidoreduction of 5-oxoalkanals appears to surpass the conventional methods of $\delta$-lactone formation.

(17) (a) J ia, X : Zhang, Y : Zhou, X Synth. Commun 1994, 24, 387. (b) Chen, R.; Zhang, Y. Synth. Commun. 1999, 29, 3699. It has been reported that disulfide RS-SR is reduced by $\mathrm{Sm}$ to give (RS) $3 \mathrm{Sm}$ by the catalysis of $\mathrm{Ph}_{2} \mathrm{CO}$. See (c) Taniguchi, Y.; Maruo, M.; Takaki, K.; Fujiwara, Y. Tetrahedron Lett. 1994, 35, 7789. 
Table 3. Comparison of Different Lewis Acids in the Reactions of 5-Oxo-5-phenylpentanal (1a) and 5-Oxotridecanal (1e)

\begin{tabular}{|c|c|c|c|c|}
\hline entry & substrate & Lewis acid (mol \%) & $\begin{array}{c}\mathrm{mol} \% \text { of } \\
\mathrm{i}-\mathrm{PrSH}\end{array}$ & $\begin{array}{l}\text { products } \\
\text { (yield, \%) }\end{array}$ \\
\hline 1 & 1a & $\mathrm{Sml}_{2}(50)$ & 40 & $2 a(99)$ \\
\hline 2 & 1a & $\mathrm{Sml}_{3}(110)$ & 100 & $3 \mathbf{a}(85)^{a}$ \\
\hline 3 & la & $\mathrm{Sml}_{3}(10)$ & 100 & $3 \mathbf{a}(75)^{a}$ \\
\hline 4 & la & $\mathrm{Sml}_{2}(25) / \mathrm{Sml}_{3}(25)$ & 20 & $2 a(67)$ \\
\hline 5 & la & $\mathrm{Sml}_{2}(50) / \mathrm{Sml}_{3}(25)$ & 20 & $\mathbf{2 a}(99)$ \\
\hline 6 & 1a & $\mathrm{SmF}_{3}(20)$ & 50 & b \\
\hline 7 & 1a & $\mathrm{SmCl}_{3}(20)$ & 50 & b \\
\hline 8 & 1a & $\mathrm{SmBr}_{3}(20)$ & 50 & b \\
\hline 9 & 1a & $\mathrm{Sm}(\mathrm{OAC})_{3}(20)$ & 50 & b \\
\hline 10 & 1a & $\mathrm{Sm}(\mathrm{OTf})_{3}(20)$ & 50 & b \\
\hline 11 & 1a & $\mathrm{Sm}(\mathrm{i}-\mathrm{PrO})_{3}(20)$ & 50 & b \\
\hline 12 & la & $\mathrm{Al}(\mathrm{i}-\mathrm{PrO})_{3}(20)$ & 50 & b \\
\hline 13 & 1a & $\mathrm{Ti}(\mathrm{i}-\mathrm{PrO})_{3}(20)$ & 50 & b \\
\hline 14 & le & $\mathrm{Sml}_{2}(50)$ & 40 & $2 e(94)$ \\
\hline 15 & le & $\mathrm{Sml}_{3}(110)$ & 100 & $3 e(87)^{a}$ \\
\hline 16 & le & $\mathrm{Sml}_{3}(10)$ & 100 & $3 e(79)^{a}$ \\
\hline
\end{tabular}

a The product $\mathbf{3 a}$ (or $\mathbf{3 e}$ ) existed as a mixture of two geometric isomers (cis/trans $=1: 1$ ). ${ }^{\text {b }}$ No compounds $\mathbf{2 a}$ or $\mathbf{3 a}$ were obtained.

Although evidence indicated that $\mathrm{Sml}_{2}$ was actually a pre-catalyst to generate the corresponding trivalent samarium species as the real Lewis acid catalyst. ${ }^{3-9}$ However, some studies (Table 3) also showed that the direct introduction of trivalent samarium species did not reach the same results as that using $\mathrm{Sml}_{2}$ precatalyst. For example, treatment of $\mathbf{l a}$ with stoichiometric amounts of $\mathrm{Sml}_{3}$ and i-PrSH gave thioenol ether 3a (85\% yield) but not lactone $\mathbf{2 a}$ (entry 2, Table 3). When the amount of $\mathrm{Sml}_{3}$ was decreased to $10 \mathrm{~mol} \%$, compound 3a was still obtained in $75 \%$ yield in the presence of i-PrSH (entry 3, Table 3). The yields of 3a changed as different amounts of i-PrSH were used. By using 20 and $40 \mathrm{~mol} \%$ of $\mathrm{i}-\mathrm{PrSH}$ along with $\mathrm{Sml}_{3}$, oxopentanal $\mathbf{l}$ a was converted to thioenol ether $3 a$ in 18 and 38\% yields, respectively. A variety of Lewis acids were also examined (entries 6-13, Table 3). However, neither $\mathrm{SmF}_{3}, \mathrm{SmCl}_{3}, \mathrm{SmBr}_{3}$, $\mathrm{Sm}(\mathrm{OAc})_{3}, \mathrm{Sm}(\mathrm{OTf})_{3}, \mathrm{Sm}(\mathrm{i}-\mathrm{PrO})_{3}, \mathrm{Al}(\mathrm{i}-\mathrm{PrO})_{3}$, nor $\mathrm{Ti}(\mathrm{i}-$ $\mathrm{PrO})_{4}$ could convert oxopentanal $\mathbf{l a}$ to lactone $\mathbf{2 a}$ or thioenol ether 3a. We speculated that $\mathrm{Sml}_{3}$ underwent an ligand exchange with i-PrSH to produce the strong acid $\mathrm{HI}$, which would promote the subsequent dehydration (a diverted elimination process of intermediate $\mathbf{A}$ in Figure 2). ${ }^{18}$ Oxopentanal $\mathbf{l a}$ remained unchanged when an equimolar amount of $\mathrm{Et}_{3} \mathrm{~N}$ or 1,8-bis(dimethylamino)naphthalene (Proton-Sponge) was added to the media of $\mathrm{Sml}_{3} / \mathrm{i}-\mathrm{PrSH}$.

When the reaction of $\mathbf{1 a}$ was conducted in the media containing both $\mathrm{Sml}_{2}$ and $\mathrm{Sml}_{3}$, the formation of lactone 2a promoted by $\mathrm{Sml}_{2}$ dominated over the formation of thioenol ether 3a promoted by $\mathrm{Sml}_{3}$ (entries 4 and 5, Table 3). The reactions of 5-oxotridecanal (1e) afforded lactone $2 \mathbf{e}$ by the catalysis of $\mathrm{Sml} / \mathrm{i}$-PrSH (entry 14 ,

(18) Condensation of carbonyl compounds with mercaptans has been achieved by the promotion of $\mathrm{TiCl}_{4} / \mathrm{Et}_{3} \mathrm{~N}$ to give thioenol ethers. See (a) Mukaiyama, T.; Saigo, K. Chem. Lett. 1973, 479. There is no previous report on the formation of thioenol ethers by using $\mathrm{Sml}_{3}$ as the promoter. In our preliminary report (ref 10), we wrongly assigned the structures of $\mathbf{3 a}$ and $\mathbf{3 e}$ as isopropyl thioesters of 5-phenylpent4-enoic acid and tridec-4-enoic acid.

\section{Scheme 3. Stereoselective Sequential Acetalization, Tishchenko Reaction, and Lactonization}
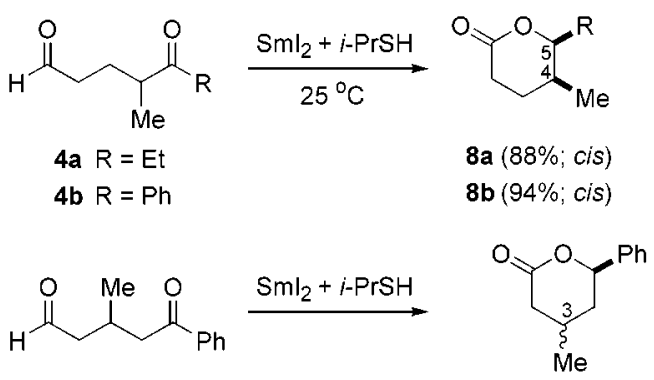

at $25^{\circ} \mathrm{C}$ at $0^{\circ} \mathrm{C}$

$(90 \% ;$ trans/cis $=94: 6)$

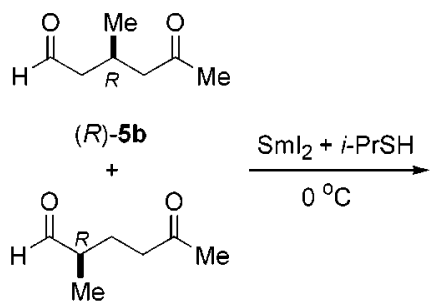

$(R)-6$

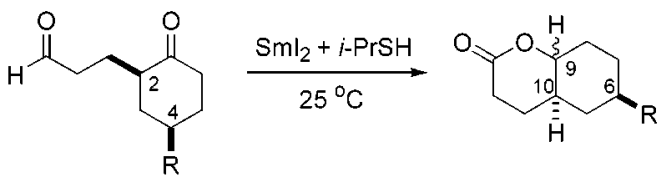

7a $\mathrm{R}=\mathrm{H}$

$7 \mathrm{~b} \mathrm{R}=t-\mathrm{Bu} ; 2,4-\mathrm{cis}$

11a $(70 \% ; 9,10-$ trans $/$ cis $=96: 4)$ 11b $(91 \% ; 9,10$-trans/cis $=81: 19)$
Table 3) and produced thioenol ether $\mathbf{3 e}$ in the presence of $\mathrm{Sml}_{3} / \mathrm{i}-\mathrm{PrSH}$ (entries 15 and 16, Table 3).

Stereochemistry. To know the stereochemistry in formation of substituted $\delta$-lactones, we synthesized the 2-, 3-, and 4-methyl-5-oxoalkanals and examined their $\mathrm{Sml} / \mathrm{i}-\mathrm{PrSH}$ promoted reactions (Scheme 3 ). Compounds $\mathbf{4 a}, \mathbf{b}, \mathbf{5} \mathbf{a}$, and $\mathbf{7 a}, \mathbf{b}$ were prepared via their hydrazone derivatives according to the procedure used for $\mathbf{l h}$ (Scheme 1). ${ }^{13}$ Thus, the hydrazones of 3-pentanone and propiophenone were alkylated with 4-bromo-1-butene, followed by ozonolysis, to give the 4-methyl-5-oxoaldehydes $\mathbf{4 a}$ and $\mathbf{4} \mathbf{b}$. The hydrazone of acetophenone was alkylated with 2-(2-iodopropyl)-1,3-dioxolane, followed by acid-catalyzed hydrolysis, to give 3-methyl-5-oxo-5-phenylpentanal (5a). The cyclic compounds $7 \mathbf{a}$ and $\mathbf{7 b}$ were similarly prepared from the hydrazone of cyclohexanone and 4-tert-butylcyclohexanone via al kylation with 2-(2iodoethyl)-1,3-dioxol ane and hydrolysis.

The Sml $/$ i-PrSH-catalyzed reactions of substituted oxoalkanals occurred in a highly stereoselective manner. Lactones $\mathbf{8 a}, \mathbf{b}, 19,20$ derived from 4-methyl-5-oxopentanals $\mathbf{4 a}, \mathbf{b}$, had a cis configuration as indicated by a small coupling constant $(3 \mathrm{~Hz}$ ) between $\mathrm{H}-4$ and $\mathrm{H}-5$. Treatment of 3-methyl-5-oxo-5-phenylpentanal (5a) with $\mathrm{Sml}_{2} /$ i-PrSH at $25^{\circ} \mathrm{C}$ in THF solution gave lactone 9 a as a mixture of trans and cis isomers (77:23). ${ }^{21}$ The trans/cis isomeric ratio was increased to $94: 6$ by performing the

(19) (a) Kobayashi, Y.; Kitano, Y.; Takeda, Y.; Sato, F. Tetrahedron Lett. 1986, 27, 2937. (b) Fereira, J. T. B.; Marques, J. A.; Marino, J. P. Tetrahedron: Asymmetry 1994, 5, 641.

(20) Oshima, M.; Yamazaki, H.; Shimizu, I.; Nisar, M.; Tsuji, J . J Am. Chem. Soc. 1989, 111, 6280. 
reaction at $0{ }^{\circ} \mathrm{C}$. The trans lactone showed an NOE correlation between $\mathrm{Me}-3$ and $\mathrm{H}-5$, whereas the cis isomer was devoid of this effect. The $\mathrm{Sml} / \mathrm{i}-\mathrm{PrSH}$ catalyzed reactions of 2-(3-oxopropyl)cyclohexanones $\mathbf{7 a , b}$ at $25^{\circ} \mathrm{C}$ afforded 1-oxa-2-decalones $\mathbf{1 1 a}$, $\mathbf{b}$ in preponderance of the 9,10-trans isomers. ${ }^{22,23}$ The trans decalones had $\mathrm{H}-9$ and $\mathrm{H}-10$ on axial positions as characterized by the ddd splitting pattern $(\mathrm{J}=10,10,4 \mathrm{~Hz})$ of $\mathrm{H}-9$ in the ${ }^{1} \mathrm{H}$ NMR spectra.

An inseparable mixture (1:1) of (R)-3-methyl-5-oxohexanal $[(R)-5 b]$ and (R)-2-methyl-5-oxohexanal [(R)-6] was prepared from (R)-3-methylcyclopentanone by a three-step sequence similar to that for $\mathbf{1 b}$ (Scheme 1). Thus, the addition reaction with $\mathrm{MeMgCl}$, followed by acid-catalyzed dehydration afforded a mixture of 1,3dimethylcyd opentene and 1,4-dimethylcydopentene, which was subjected to ozonolysis to give (R)-5b and (R)-6. Treatment of the mixture of (R)-5b and (R)-6 (1:1) with $\mathrm{Sml}_{2}(50 \mathrm{~mol} \%)$ and i-PrSH $(40 \mathrm{~mol} \%)$ at $0{ }^{\circ} \mathrm{C}$ gave a mixture of lactones (3S,5S)-9b and (2R,5S)-10 (1:1) according to the ${ }^{1} \mathrm{H} N M R$ analysis. The analytic samples of lactones (3S,5S)-9b and (2R,5S)-10 were isolated by HPLC, and their optical rotations were in agreement with the reported values. ${ }^{24,25}$ The enantiomer of lactone $(2 R, 5 S)$ $\mathbf{1 0}$ is a pheromone of carpenter bee (Xylocopa hirsutissima). ${ }^{25}$

The stereochemical outcomes can be interpreted by comparisons of the transition states $\mathbf{C}$ versus $\mathbf{D}$ and $\mathbf{E}$ versus $\mathbf{F}$. Transition state $\mathbf{C}$, giving cis-8a, $\mathbf{b}$, trans-9a, $\mathbf{b}$, and cis-10 is energetically favored due to the equatorial dispositions of substituents $\left(R^{2}, R^{3}\right.$, and $\left.R^{4}\right)$, whereas the alternative transition state $\mathbf{D}$ exerts steric repulsions due to the axially oriented substituents. Transition state $\mathbf{E}$, giving trans-11a,b, having hydride attack the cyclohexanone moiety from the axial direction is superior to an equatorial attack in the transition state $\mathbf{F}$. Many previous studies support that axial $\mathrm{H}^{-}$delivery to cyclohexanones is a kinetically favored process. ${ }^{3 d}$ Under such circumstances, product development control also favors formation of the more stable equatorial alcohol (as shown in E). The stereoselectivities are in agreement with the previous findings ${ }^{3 d, 7 c}$ of the related intermolecular Tishchenko reactions.

Synthesis of optically Active $\delta$-Lactones. For the synthesis of optically active $\delta$-lactones, many methods rely on obtaining chiral 5-hydroxyalkanoic acids or derivatives as the requisite starting materials. The asymmetric synthesis of $\delta$-alkyl- $\delta$-lactones, as those found in nature as sex pheromones, has extra difficulties

(21) Barbero, A.; Blakemore, D. C.; Fleming, I.; Wesley, R. N. J . Chem. Soc., Perkin Trans. 1 1997, 1329.

(22) (a) Forzato, C.; Nitti, P.; Pitacco, G.; Valentin, E. Tetrahedron: Asymmetry 1999, 10, 1243. (b) Griffiths, D. V.; Wilcox, G. J. Chem. Soc., Perkin Trans. 2 1988, 431. (c) Chandrasekhar, S.; Venkatesan, V. J. Chem. Research (M), 1995, 1137. It has been reported (ref 22c) that 2-(3-oxopropyl)cyclohexanone (7a) underwent an intramolecular Cannizzaro reaction in boiling $\mathrm{NaOH}$ solution $(3 \mathrm{M})$ to give $3-(2$ hydroxycycl ohexyl)propionic acid, which was subjected to lactonization on treatment with concentrated $\mathrm{HCl}$ to give exclusively the trans isomer of 11a (59\%), based on an analysis of the ${ }^{1} \mathrm{H}$ NMR spectrum $(90 \mathrm{MHz})$. In our hand, the two-step reaction afforded a trans/cis mixture of 11a in a ratio of 91:9 based on an analysis of the ${ }^{1} \mathrm{H} N \mathrm{NR}$ spectrum $(300 \mathrm{MHz})$.

(23) Edward, J . T.; Cooke, E.; Paradellis, T. C. Can. J . Chem. 1982, $60,2546$.

(24) Carroll, F. J .; Meck, R. Synth. Commun. 1971, 169. Carroll, F. J .; Meck, R. J . Org. Chem. 1974, 39, 3890.

(25) (a) Mori, K.; Senda, S. Tetrahedron 1985, 41, 541. (b) Katsuki, T.; Yamaguchi, M. Tetrahedron Lett. 1987, 28, 651. (c) Schink, H. E.; Baeckvall, J .-E. J . Org. Chem. 1992, 57, 1588. in obtaining long-chain aliphatic precursors with chiral carbinyl centers. A general approach to $\delta$-alkyl- $\delta$-lactones utilizes the natural source of chiral alcohols, which are elaborated (often in a lengthy sequence) to reach the target molecules. For example, ${ }^{25 a}(\mathrm{~S})$-lactate and (R)- $\beta$ hydroxyisobutyrate have been used to synthesize a sex pheromone, (2S,5R)-2-hexanolide (10), in a ten-step sequence. Chemical resolution of alcohols, by derivatization and chromatographic separation, has provided an al ternative source of optically active 5-hydroxy-6-hexadecynenitrile, ${ }^{26}$ which is further elaborated to a pheromone of Oriental hornet (Vespa orientalis), (R)-5-hexadecanolide (2j). Although asymmetric reduction ${ }^{27}$ of phenones and the ketones with adjuvant groups (e.g., $\alpha$-methoxyketones and $\beta$-ketoesters) has advanced in this decade, the highly enantioselective reduction of unsubstituted long-chain al iphatic ketones remains a challenging task. ${ }^{28}$ Microbial reduction (e.g., using bakers' yeast) ${ }^{29}$ has shown some success in this aspect, but it is still limited by low yielding and substrate specificity.

As to the samarium ion catalyzed reactions, we synthesized many optically active $\delta$-lactones via three routes: (i) using chiral 5-oxoalkanals such as (S)-6, (ii) using stoichiometric amount of chiral alcohols to react with 5-oxoalkanals, and (iii) using catalytic amount of chiral mercaptan to promote the conversion of 5-oxoalkanals. All three methods showed a common feature of remotecontrol to establish thechirality of carbinyl center at C-5.

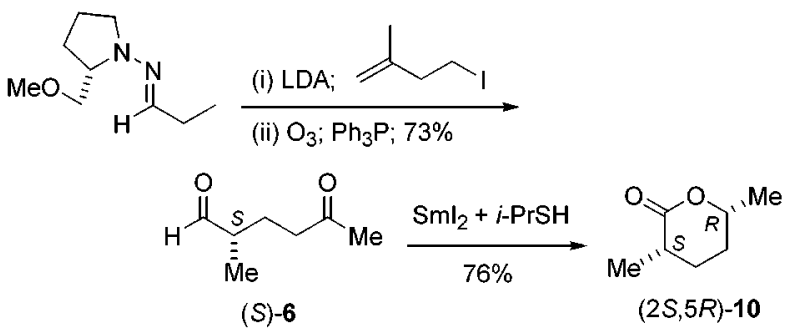

(2)

To prepare (S)-2-methyl-5-oxohexanal (6), propionaldehyde was condensed with (S)-1-amino-2-(methoxymethyl)pyrrolidine (SAMP) ${ }^{30}$ to give a chiral hydrazone (eq 2). Alkylation of such hydrazone with 4-iodo-2-methyl1-butene, followed by ozonolysis, thus occurred in a highly stereoselective fashion to give (S)-6. Treatment of (S)-6 with $\mathrm{Sml}_{2}(50 \mathrm{~mol} \%)$ and i-PrSH (40 mol \%) afforded (2S,5R)-2-methylhexanolide (10) exclusively. The melting point $\left(40-42{ }^{\circ} \mathrm{C}\right)$ and optical rotation $\left([\alpha]_{D}+63.5\right)$ were in agreement with the values reported for the natural product. ${ }^{25}$ The stereochemistry was consistent with the mirror image of transition state $\mathbf{C}$ (Figure 3), in which $\mathrm{R}=\mathrm{R}^{2}=$ Me and $\mathrm{R}^{3}=\mathrm{R}^{4}=\mathrm{H}$. The preferable equatorial

(26) Pirkle, W. H.; Adams, P. E. J . Org. Chem. 1979, 44, 2169.

(27) (a) Nishizawa, M.; Noyori, R. In Comprehensive Organic Synthesis; Trost, B. M., Fleming, I., Eds.; Pergamon Press: Oxford, 1991; Vol. 8, pp 159-182. (b) Singh, V. K. Synthesis 1992, 605. (c) Downham, R.; Edwards, P. J .; Entwistle, D. A.; Hughes, A. B.; Kim, K. S.; Ley, S. V. Tetrahedron: Asymmetry 1995, 6, 2403.

(28) (a) Imai, T.; Tamura, T.; Yamamura, A.; Sato, T.; Wollmann T. A.; Kennedy, R. M.; Masamune, S. J . Am. Chem. Soc. 1986, 108 7402. (b) Brown, H. C.; Ramachandran, P. V. J . Org. Chem. 1989, 54, 4504.

(29) (a) Utake, M.; Watabu, H.; Takeda, A. J . Org. Chem. 1987, 52, 4363. (b) Haase, B.; Schneider, M. P. Tetrahedron: Asymmetry 1993: 4, 1017.

(30) (a) Enders, D.; Kipphardt, H.; Fey, P. Org. Synth. 1987, 65, 183. (b) Enders, D.; Bockstiegel, B. Synthesis 1989, 7, 493. 


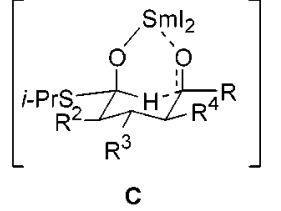

vs
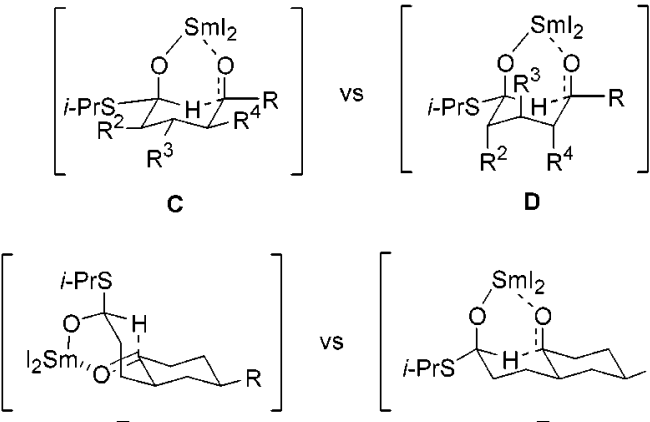

$\mathbf{E}$

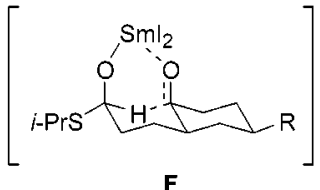

$\mathbf{F}$
Figure 3. Transition states in the $\mathrm{Sml}_{2} / \mathrm{i}-\mathrm{PrSH}$ promoted reactions of substituted 5 -oxoalkanals $\mathbf{4 a}-\mathbf{7 b}$. Transition state C having equatorial substituents is favored over transition state D having axial substituents. Transition state $\mathbf{E}$ with hydride transfer to the axial positions of cyclohexanones is favored over transition state $\mathbf{F}$ with hydride transfer to the equatorial positions of cyclohexanones.

orientation of $\mathrm{R}^{2}$ group at $\mathrm{C}-2$ determined the newly generated stereocenter at $\mathrm{C}-5$ in a sense of remote control.

As shown in Table 4, the reaction of oxopentanal 1a with (-)-menthol (110 mol \%) was promoted by $\mathrm{Sml}_{2}$ (100 mol \%) to give the desired 5-hydroxy ester 12a (61\%), along with diester $\mathbf{1 3 a}(31 \%)$ and pinacol 14a (8\%). The

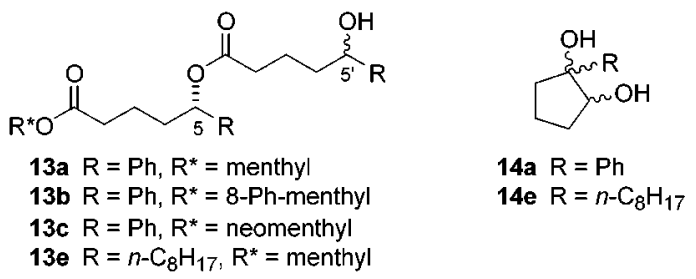

hydroxyester 12a was saponified and treated with acid to give lactone $\mathbf{2 a}$ with predominance of the (S)-enantiomer ( $84 \%$ ee) as determined by HPLC analysis on a Chiralcel OB column. ${ }^{31}$ The diastereomeric excess of hydroxyester 12 a was deduced to be $84 \%$ by anal ogy to that of lactone $\mathbf{2 a}$, although our primary examination of 12a with $300 \mathrm{MHz}$ NMR or HPLC analyses could not tell the difference of two diastereomers. Diester 13a could be derived either by transesterification between two molecules of hydroxyester 12a, or by the second acetalization-Tishcheko reaction of oxopentanal la with hydroxyester 12a. A clue was found by the following experiment. In the presence of $\mathrm{Sml}_{2}$, oxopentanal $\mathbf{l a}$ ( $84 \%$ ee) was treated with an equimolar amount of hydroxyester 12a in THF at room temperature for 30 min to give a mixture of $\mathbf{1 2} \mathbf{a}(45 \%), \mathbf{1 3} \mathbf{a}(35 \%)$, and $\mathbf{2 a}(20 \%)$. The mixture was then treated with trifluoroacetic adid in $\mathrm{CH}_{2-}$ $\mathrm{Cl}_{2}$ to give lactone $2 \mathbf{a}$ ( $87 \%$ overall yield) with $72 \%$ ee in favor of the (S)-enantiomer. The ee value should keep unchanged if diester 13a were formed by transesterification of two molecules of hydroxyester 12a. As the ee values varied, oxopentanal $\mathbf{1 a}$ and hydroxyester $\mathbf{1 2 a}$ likely underwent the tandem acetalization-Tishchenko reaction to give 13 a with a predominance of the $\left(5 S, 5^{\prime} R\right)$ isomer. The subsequent lactonization would give both (S)and $(\mathrm{R})$-enantiomers of $\mathbf{2} \mathbf{a}$, causing the ee value lower

(31) (a) Bolm, C.; Schlinggl off, G.; Weickhardt, K. Angew. Chem., Int. Ed. Engl. 1994, 33, 1848.' (b) Downham, R.; Edwards, P. J.; Entwistle, D. A.; Hughes, A. B.; Kim, K. S.; Ley, S. V. Tetrahedron: Asymmetry 1995, 6, 2403. than $84 \%$. It appeared that (-)-menthol with (R)-chirality at the carbinyl center directed the (S)-chirality in hydroxyester 12a, whereas hydroxyester 12a with (S)chirality guided the $\left(5^{\prime} \mathrm{R}\right)$-chirality in diester $\mathbf{1 3 a}$.

By the promotion of $\mathrm{Sml}_{2}$, oxopentanal $\mathbf{l a}$ reacted with (-)-8-phenylmenthol to give hydroxyester $\mathbf{1 2 b}(48 \%$ yield), which was subsequently converted to lactone $\mathbf{2 a}$ with $72 \%$ ee in favor of the (S)-enantiomer. The reaction of 1a with (+)-neomenthol gave a low yield (4\%) of hydroxyester 12c with decreasing stereoselectivity as deduced by its conversion to lactone $\mathbf{2 a}$ of $21 \%$ ee (entry 3 , Table 4). To avoid the complication of pinacolic coupling reactions, oxopentanal la was treated with $\mathrm{Sml}_{3}$ $(20 \mathrm{~mol} \%)$ and (-)-menthol (100 mol \%) in refluxing THF for $1 \mathrm{~h}$ (entry 4, Table 4). The crude product mixture was subsequently treated with trifluoroacetic acid in $\mathrm{CH}_{2} \mathrm{Cl}_{2}$ to give lactone $\mathbf{2 a}$ ( $65 \%$ overall yield) with $78 \%$ ee in favor of the (S)-enantiomer.

The $\mathrm{Sml}_{2}$-promoted reaction of 5-oxotridecanal (1e) with (-)-menthol afforded hydroxyester 12e (51\%), diester $\mathbf{1 3 e}(20 \%)$, pinacol $\mathbf{1 4 e}(20 \%)$, and lactone $\mathbf{2 e}(9 \%)$. The lactone $\mathbf{2 e}$ obtained directly from this reaction had $32 \%$ ee in favor of the (R)-enantiomer, whereas hydroxyester $\mathbf{1 2}$ e was saponified and subjected to cyclization to give lactone $\mathbf{2 e}$ with $\mathbf{7 2} \%$ ee in favor of the (R)-enantiomer. ${ }^{32}$ When oxoalkanal $\mathbf{l e}$ was heated with (-)-menthol (100 $\mathrm{mol} \%$ ) and $\mathrm{Sml}_{3}$ in refluxing THF, lactone $\mathbf{2 e}$ (31\% ee) was obtained after the subsequent treatment with $\mathrm{CF}_{3} \mathrm{CO}_{2} \mathrm{H}$ (entry 6, Table 4).

As we have demonstrated that oxoalkanals $\mathbf{l a}-\mathbf{i}$ could be converted directly to $\delta$-lactones $\mathbf{2} \mathbf{a}-\mathbf{i}$ by the synergistic catalysis of $\mathrm{Sml}_{2}$ and mercaptan, we also wished to investigate whether the related asymmetric reactions could be achieved in the presence of chiral additives? Using the $\mathrm{Sml}_{2} / \mathrm{i}$-PrSH-promoted reaction of 5-oxotridecanal (1e) as a model, several additives were examined. The reaction of 1 e with $\mathrm{Sml}_{2}$ (50 mol \%), i-PrSH (40 mol $\%$, and (S)-1,1-bi-2-naphthol (50 mol \%) at room temperature gave lactone $\mathbf{2 e}$ (42\% yield) with $15 \%$ ee in favor of the (R)-enantiomer. No asymmetric induction was found with the chiral additives of (-)-sparteine, bisphosphoramide $\mathbf{1 5 ^ { 3 3 }}$, or salen $\mathbf{1 6 .}{ }^{34}$ In the presence of (R)-
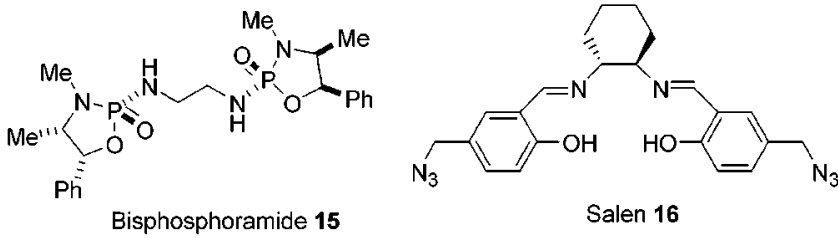

methyl p-tolylsulfoxide or (S)-proline, a reductive coupling reaction of $\mathbf{l e}$ was effected by $\mathrm{Sml}_{2}$ to give pinacol $\mathbf{1 4 e}$, instead of the desired lactone $\mathbf{2 e}$.

As we have shown that chiral alcohols did induce the reactions of 5-oxoalkanals to give optically enriched 5 -hydroxyesters and $\delta$-lactones, we wished to devise the asymmetric catalytic reactions of 5-oxoalkanals by using chiral mercaptans to facilitate the formation of chiral $\delta$-lactones. There are only a few chiral mercaptans available in nature; we thus prepared a series of chiral

(32) (a) Utaka, M.; Watabu, H.; Takeda, A. Chem. Lett. 1985, 1475 (b) Godnon, R.; Grogan, G.; Levitt, M. S.; Roberts, S. M.; Wan, P. W. H.; Willetts, A. J . J . Chem. Soc., Perkin Trans. 1 1994, 2537.

(33) Yang, W.-B.; Fang, J .-M. J . Org. Chem. 1998, 63, 1356.

(34) (a) Pozzi, G.; Cavazzini, M.; Cinato, F.; Montanari, F.; Quici, S. Eur. J . Org. Chem. 1999, 1947, 7. 
Table 4. Samarium Ion Promoted Reactions of 5-Oxoalkanals with Chiral Alcohols (Step i), and the Subsequent Lactonization (Step ii)

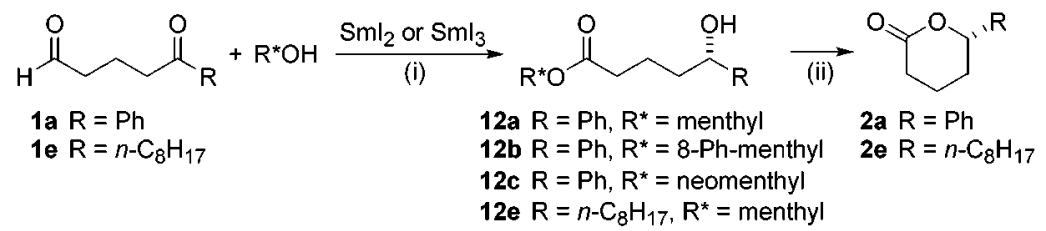

\begin{tabular}{|c|c|c|c|c|c|c|}
\hline entry & substrate & $\mathrm{R} * \mathrm{OH}$ & $\begin{array}{l}\text { promoter } \\
\text { (mol \%) }\end{array}$ & $\begin{array}{c}\text { step i } \\
\text { (yield, \%) }\end{array}$ & $\begin{array}{c}\text { step ii } \\
\text { (yield, \%) }\end{array}$ & $\begin{array}{c}\text { configurationa }^{a} \\
\text { (\% ee) }\end{array}$ \\
\hline $\begin{array}{l}1 \\
2 \\
3 \\
4 \\
5 \\
6\end{array}$ & $\begin{array}{l}\text { la } \\
\text { la } \\
\text { la } \\
\text { la } \\
\text { le } \\
\text { le }\end{array}$ & $\begin{array}{l}\text { (-)-menthol } \\
\text { (-)-8-Ph-menthol } \\
(+) \text {-neomenthol } \\
\text { (-)-menthol } \\
\text { (-)-menthol } \\
(-) \text {-menthol }\end{array}$ & $\begin{array}{l}\mathrm{Sml}_{2}(100) \\
\mathrm{Sml}_{2}(100) \\
\mathrm{Sml}_{2}(100) \\
\mathrm{Sml}_{3}(20) \\
\mathrm{Sml}_{2}(100) \\
\mathrm{Sml}_{3}(20)\end{array}$ & $\begin{array}{l}\text { 12a }(61)^{b} \\
12 b(48)^{c} \\
12 c c(4)^{d} \\
-e \\
12 e(51)^{f} \\
-e\end{array}$ & $\begin{array}{l}\mathbf{2 a}(65) \\
\mathbf{2 a}(77) \\
\mathbf{2 a}(70) \\
\mathbf{2 a}(65) \\
\mathbf{2 e}(69) \\
\mathbf{2 e}(58)\end{array}$ & $\begin{array}{l}\text { S (84) } \\
S(72) \\
R(21) \\
S(78) \\
R(72) \\
R(31)\end{array}$ \\
\hline
\end{tabular}

a The configuration of the major enantiomers of lactonic products. b This reaction also gave diester $\mathbf{1 3 a}(31 \%)$ and pinacol $\mathbf{1 4 a}(8 \%)$. c This reaction also gave lactone $\mathbf{2 a}(21 \%)$, diester $\mathbf{1 3 b}(25 \%)$ and pinacol $\mathbf{1 4 a}(6 \%)$. d This reaction also gave lactone $\mathbf{2 a}(\mathbf{1 4 \%})$, diester $\mathbf{1 3}$ c (52\%), and pinacol $\mathbf{1 4 a}(29 \%)$. ${ }^{e}$ The reaction mixture was directly treated with $\mathrm{CF}_{3} \mathrm{CO}_{2} \mathrm{H}_{\text {in }} \mathrm{CH}_{2} \mathrm{Cl}_{2}$ to give lactone $\mathbf{2 a}$ (or $\mathbf{2 e}$ ). ${ }^{f}$ This reaction also gave lactone $\mathbf{2 b}$ ( $9 \%$ yield, $32 \%$ ee), diester $\mathbf{1 3 e}(20 \%)$ and pinacol $\mathbf{1 4 e}(20 \%)$.

mercaptans $\mathbf{1 7}-\mathbf{3 8}$ by derivatization of terpene alcohols, sterols, $\alpha$-amino acids, and $\beta$-amino alcohols (Scheme 4 ). We also utilized the reaction of 5-oxotridecanal (1e) as a model to study the effects of chiral mercaptans on the enantioselective synthesis of $\delta$-lactone $\mathbf{2 e}$.

The tosylate ester of (-)-menthol was treated with potassium thioacetate (ACSK), followed by reduction with DIBAL to give neomenthanethiol $\mathbf{1 7},{ }^{35}$ a reminiscent of neomenthol. In the presence of $\mathrm{Sml}_{2}(40 \mathrm{~mol} \%)$ and mercaptan $\mathbf{1 7}$ (50 mol \%), 5-oxotridecanal was converted to lactone $\mathbf{2 e}$ (37\% yield) in favor of the (S)-enantiomer (18\% ee). The ee value was determined by HPLC analysis on a Chiracel OB column, and the absolute configuration of the preferable enantiomer was determined by comparison with the optical rotation of the authentic sample reported in the literature. ${ }^{32}$ Since menthol exerted a higher asymmetric induction than neomenthol in the reaction with 5-oxoal kanal (compared entries 1 and 3 in Table 4), menthanethiol might be a better promoter for the enantiosel ective reaction of 5-oxoalkanal. However, attempts to prepare pure menthanethiol failed. The tosylate ester of (-)-menthol, having the tosyl oxy group on the axial position, underwent elimination on treatment with ACSK, instead of the desired $\mathrm{S}_{\mathrm{N}} 2$ reaction. Treatment of the dithiolane derivative of $(-)$-menthone with BuLi gave a mixture of menthanethiol and neomenthanethiol, ${ }^{36}$ which could not be separated by chromatography. The reaction of $\mathbf{1 e}$ with this mixture and $\mathrm{Sml}_{2}$ gave $80 \%$ yield of $\mathbf{2 e}$ with $33 \%$ ee in favor of the (S)-enantiomer. One might argue whether using enantiomerically pure menthanethiol as the promoter would enhance the enantioselective reaction?

When the pinane-type mercaptan $\mathbf{1 8}^{37}$ and the cholesterol-type mercaptan $\mathbf{1 9}^{38}$ were used together with $\mathrm{Sml}_{2}$, the reactions of $\mathbf{l e}$ gave lactone $\mathbf{2 e}$ in 20 and $\mathbf{1 4 \%}$ ee, respectively, in favor of the (R)-enantiomer. We speculated that an annexed group at the neighboring position of the thiol might help in chelation with samarium ion,

(35) Taj, S. S.; Soman, R. Tetrahedron: Asymmetry 1994, 5, 1513. Mikolajczyk, M.; Perlikowska, W.; Omelanczuk, J. Synthesis 1987 1009.

(36) Wilson, S. R.; Georgiadis, G. M.; Khatri, H. N.; Bartmess, J . E. J. Am. Chem. Soc. 1980, 102, 3577.

(37) Aggarwal, V. K.; Kalomiri, M.; Thomas, A. P. Tetrahedron: Asymmetry 1994, 5, 723.

(38) (a) Volante, R. P. Tetrahedron Lett. 1981, 22, 3119. (b) Hojo, K.; Yoshino, H.; Mukaiyama, T. Chem. Lett. 1977, 437. and thus improved the enantioselectivity in the reaction with 1e. I ndeed, the reaction occurred in higher enantioselectivities ( 38 and $44 \%$ ee) by using the camphor-type mercaptans ${ }^{39} \mathbf{2 0}$ and $\mathbf{2 1}$ annexed with hydroxyl groups. However, the reaction using the camphor-type mercap$\operatorname{tans}^{39}$ 22-24 with neighboring alkoxy groups did not show any improved enantioselectivity (12-22\% ee). It was noted that the isomeric mercaptans $\mathbf{2 2}$ and $\mathbf{2 4}$ showed the opposite enantiotopic preference in promoting lactone formation, a phenomenon also observed in the reactions promoted by menthol and neomenthol.

Derivatization of L-cysteine and (S)-proline gave the chiral mercaptans $25^{40}$ and $\mathbf{2 6},{ }^{41}$ of which the $\beta$-carbons are chiral but the $\alpha$-carbons are achiral. The enantioselectivities in the $\mathrm{Sml}_{2}$ promoted reactions of $\mathbf{l e}$ with mercaptans $\mathbf{2 5}$ or $\mathbf{2 6}$ and $\mathrm{Sml}_{2}$ turn out to be low, giving 24 and $10 \%$ ee of lactone $\mathbf{2 e}$. We found that the ephedrine-related mercaptans containing stereocenters at both $\alpha$ - and $\beta$-carbons showed higher enantioselectivities (up to $68 \%$ ee). The ephedrine-related mercaptans were generally prepared via the ring-opening reactions of aziridines with thio acids (Scheme 5 ). ${ }^{42}$ For example, $(1 \mathrm{R}, 2 \mathrm{~S})-(-)$-norephedrine underwent a Mitsunobu reaction (DIAD, $\mathrm{Ph}_{3} \mathrm{P}, \mathrm{Et}_{3} \mathrm{~N}$ ) to give an aziridine, which was then treated with thioacetic acid to give mercaptan $\mathbf{3 0}$ after an in situ migration of the acetyl group. The chirality at $\mathrm{C}-1$ was unchanged due to the double $\mathrm{S}_{\mathrm{N}} 2$ reactions. ${ }^{42}$ The structure of $\mathbf{3 0}$ was confirmed by an $X$-ray diffraction analysis. Mercaptan $\mathbf{3 3}^{42}$ was similarly prepared form (1R,2S)-(-)-ephedrinium chloride, whereas mercaptan 36 was prepared from (1R,2R)-(-)-pseudoephedrine. Mercaptans $\mathbf{3 7}$ and $\mathbf{3 8}$ were prepared from (1S,2R)-(+)-2-amino-1,2-diphenylethanol.

By comparison of the reactions of $\mathbf{l e}$ promoted by $\mathrm{Sml}_{2}$ and mercaptans 27-38, it appeared that the chirality of the lactonic product $\mathbf{2 e}$ was dictated by the chirality at

(39) (a) Goodridge, R. J .; Hambley, T. W.; Haynes, R. K.; Ridley, D. D. J. Org. Chem. 1988, 53, 2881. (b) Lee, D.-S.; Huang, S.-M.; Lai, M.-C.; Chu, H.-Y.; Tang, T.-K. Org. Prep. Proc. Int. 1993, 25, 673. (c) Yang, T.-K.; Chu, H.-Y.; Lee, D.-S.; J iang, Y.-Z.; Chou, T.-S. Tetrahe dron Lett. 1996, 37, 4537.

(40) (a) Lesk, A.; Nudelman, A. Synth. Commun. 1999, 29, 1405 (b) Uhrig, R. K.; Picard, M. A.; Beyreuther, K.; Wiessler, M. Carbohydr. Res. 2000, 325, 72.

(41) Gibson, C. L. Tetrahedron: Asymmetry 1999, 10, 1551.

(42) (a) Poelert, M. A.; Hof, R. P.; Peper, N. C. M. W.; Kellogg, R. M. Heterocycles 1994, 37, 461. (b) Kang, J .; Kim, D. S.; Kim, J . I Synlett 1994, 842. 
Scheme 4 Enantioselective Formation of $\delta$-Lactone $2 \mathrm{e}$ by Treatment of $\mathrm{le}$ with $\mathrm{Sml}_{2}$ and Chiral Mercaptans in THF at $0^{\circ} \mathrm{C}$

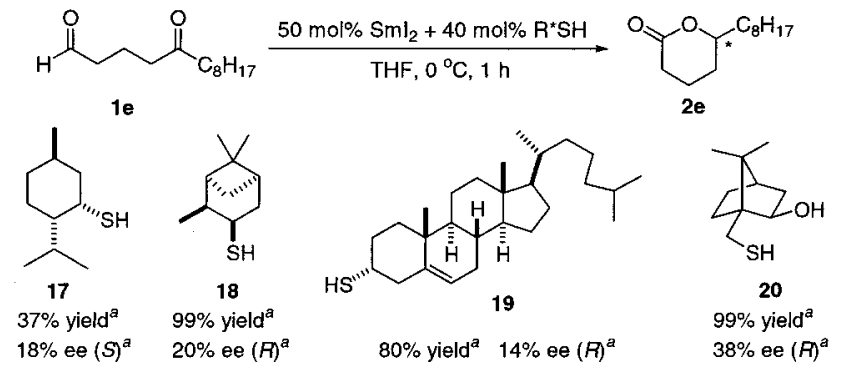

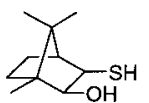

21

$83 \%$ yield $^{a}$

$44 \%$ ee $(R)^{a}$<smiles>CCOC(=O)[C@H](CS)NC(C)=O</smiles>

25

$99 \%$ yield $^{a}$

$24 \%$ ee $(R)^{a}$

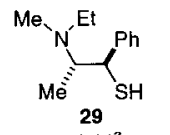

$99 \%$ yield $^{a}$

$29 \%$ ee $(A)^{a}$

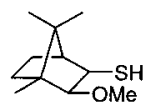

22

$22 \%$ ee $(R)^{a}$

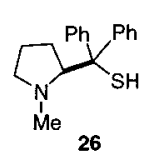

$79 \%$ yield $^{a}$

$10 \%$ ee $(R)^{a}$

$\stackrel{\mathrm{Me}}{=0}$

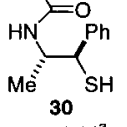

$75 \%$ yield $^{a}$

$68 \%$ ee $(A)^{a}$
$99 \%$ yield $^{a}$
23

$22 \%$ ee $(R)^{a}$

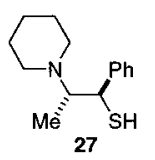

$74 \%$ yield $^{a}$

$25 \%$ ee $(F)^{a}$

$\mathrm{Ph}$

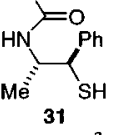

$64 \%$ yield ${ }^{a}$

$45 \%$ ee $(A)^{a}$

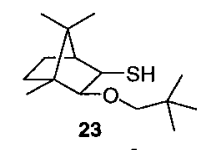

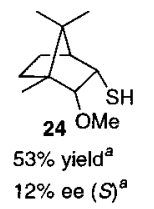

Bn

Mề 28

$71 \%$ yieid $^{a}$

$21 \%$ ee $(A)^{a}$

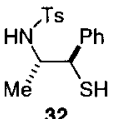

$90 \%$ yield $^{a}$

$27 \%$ ee $(A)^{a}$

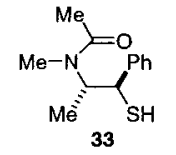

$86 \%$ yield $^{a}$

$52 \%$ ee $(F)^{a}$

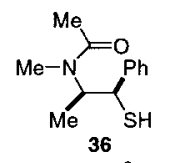

$87 \%$ yield $^{a}$

$39 \%$ ee $(A)^{a}$

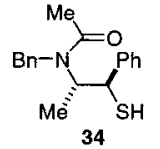

$68 \%$ yield $^{a}$

$31 \%$ ee $(R)^{a}$

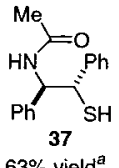

$63 \%$ yield $^{a}$

$53 \%$ ee $(S)^{a}$

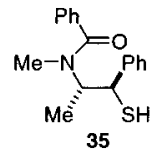

$70 \%$ yield $^{a}$

$53 \%$ ee $(R)^{\text {a }}$

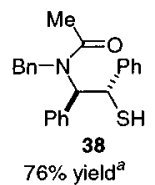

$34 \%$ ee $(S)^{a}$ a Referring to the yield and ee value of the lactonic product $\mathbf{2 e}$ obtained by using the individual mercaptan promoter.

\section{Scheme 5. Preparation of E phedrine-R elated Mercaptans via the Aziridine Intermediates}

$$
\text { Me, } \underbrace{\mathrm{NHR}}_{\mathrm{OH}} \stackrel{\mathrm{Ph}_{3} \mathrm{P}, \mathrm{DIAD}, \mathrm{Et}_{3} \mathrm{~N}}{\longrightarrow}
$$

Norephedrine, $\mathrm{R}=\mathrm{H}$

Ephedrine, $\mathrm{R}=\mathrm{Me}$

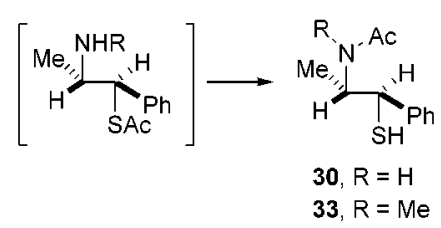

the $\alpha$-carbons of mercaptans. For example, the mercaptans 30, 33, and 36 with (R)-chirality at the $\alpha$-carbons induced the ( $\mathrm{R}$ )-enriched lactone $\mathbf{2} \mathbf{a}$, whereas the mercaptans $\mathbf{3 7}$ and $\mathbf{3 8}$ with (S)-chirality at the $\alpha$-carbons promoted the formation of (S)-enriched $\mathbf{2 e}$. The chirality at the $\beta$-carbons of mercaptans hardly had influence on
Table 5. Reactions of 5-Oxoalkanals Promoted by $\mathrm{Sml}_{2}$ (50 mol \%) and Mercaptan $30(40 \mathrm{~mol} \%)$ at $0{ }^{\circ} \mathrm{C}$ in THF Solution

\begin{tabular}{|c|c|c|c|c|c|}
\hline entry & substrate & $\mathrm{R}$ & $\begin{array}{l}\text { product } \\
\text { (yield, \%) }\end{array}$ & $\begin{array}{c}\% \text { ee } \\
\text { (configuration)a }^{\mathrm{a}}\end{array}$ & {$[\alpha]_{D}$} \\
\hline 1 & 1a & $\mathrm{Ph}$ & $2 a(83)$ & 49 (S) & -19.1 \\
\hline 2 & $\mathbf{1 b}$ & $\mathrm{Me}$ & $2 \mathrm{~b}$ & $47(\mathrm{R})$ & +14.8 \\
\hline 3 & 1d & n-hexyl & $\mathbf{2 d}(80)$ & $40(R)$ & +18.6 \\
\hline 4 & le & n-octyl & $2 \mathbf{e}(75)$ & $68(R)$ & +22.0 \\
\hline 5 & If & benzyl & $2 f(73)$ & $48^{b}$ & +7.7 \\
\hline 6 & 19 & c-hexyl & $2 \mathbf{g}(74)$ & $43^{b}$ & -11.3 \\
\hline 7 & lh & $\mathrm{t}-\mathrm{Bu}$ & $\mathbf{2 h}(73)$ & $44^{b}$ & -12.0 \\
\hline 8 & $\mathbf{1 j}$ & n-undecyl & 2j (75) & $74(\mathrm{R})$ & +27.9 \\
\hline 9 & $\mathbf{1 k}$ & n-tetradecyl & $2 \mathbf{k}(76)$ & $63^{b}$ & +16.0 \\
\hline 10 & 11 & n-octadecyl & 2l (84) & $65^{b}$ & +10.2 \\
\hline 11 & Im & $\mathrm{o}-\mathrm{MeOC}_{6} \mathrm{H}_{4}$ & $2 \mathbf{m}(74)$ & $49^{b}$ & -9.4 \\
\hline
\end{tabular}

a The absolute configuration of major enantiomer. The ee value was determined by HPLC analysis on chiral columns. The absolute configuration of major enantiomer was determined by comparison of optical rotation with that reported in the literature. ${ }^{b}$ The absolute configuration of major enantiomer was not determined.

the enanatiomeric preference of lactone $\mathbf{2 e}$. The reactions using mercaptans with the neighboring acetamido group appeared to give lactone $\mathbf{2} \mathbf{a}$ in a higher ee value (compared mercaptan $\mathbf{3 0}$ with $\mathbf{2 9}$ and $\mathbf{3 3}$ ). Among the examined examples, we obtained a $75 \%$ yield of $(R)$-enriched lactone $\mathbf{2 e}(68 \%$ ee) by treatment of 5-oxotridecanal with $\mathrm{Sml}_{2}(50 \mathrm{~mol} \%)$ and mercaptan 30 (40 mol \%) in THF at $0{ }^{\circ} \mathrm{C}$ for $1 \mathrm{~h}$.

Mercaptan $\mathbf{3 0}$ was also applied to the enantioselective synthesis of other $\delta$-lactones (Table 5). A series of optically enriched $\delta$-lactones $\mathbf{2} \mathbf{a}-\mathbf{m}$ was obtained by treatments of 5-oxoalkanals $\mathbf{1 a}-\mathbf{m}$ with $\mathrm{Sml}_{2}$ (50 mol \%) and mercaptan $\mathbf{3 0}$ (40 mol \%). All the reactions occurred in a consistent enantiotopic preference. The observed enantioselectivity was accounted on the intramolecular hydride transfer to the 5-keto group, similar to the intermediate $\mathbf{A}$ depicted in Figure 2. Thus, the major 5-phenyl lactones $\mathbf{l a}$ and $\mathbf{1 m}$ have the (S)-configuration via the si-face hydride transfer, whereas the major lactones $\mathbf{1 b}, \mathbf{1 d}, \mathbf{l e}$, and $\mathbf{1 j}$ with primary alkyl substituents have the $(R)$-configuration via the reface hydride transfer. Accordingly, a hornet pheromone (R)-5-hexadecanol ide ${ }^{43}$ ( $74 \%$ ee) was synthesized in $75 \%$ yiel d from 5-oxohexadecanal (entry 8, Table 5). The major enantiomers of $\mathbf{2 a}, \mathbf{2 f}$, and $\mathbf{2} \mathbf{m}$ having phenyl substituents tended to be less retained in Chiralcel $\mathrm{OB}$ and $\mathrm{OB}-\mathrm{H}$ columns than their corresponding minor enantiomers. On the other hand, the major enantiomers of $\mathbf{2} \mathbf{b}, \mathbf{2} \mathbf{d}, \mathbf{2} \mathbf{e}$, and 2g-I with alkyl substituents had longer retetion times on the chiral columns. It was noted that lactones $\mathbf{2} \mathbf{a}$ and $\mathbf{2 m}$ were formed in the same enantioselectivity (entries 1 and 11, Table 5), even though the ortho methoxy group of $\mathbf{I m}$ might involve in the coordination with samarium ion.

Conclusion. We have demonstrated a general method for conversion of various 5-oxoalkanals to substituted $\delta$-lactones and 1-oxa-2-decalones by the synergistic ca-

(43) (a) Taberm D. F.; Deker, P.; Gaul, M. D. J . Am. Chem. Soc 1987, 109, 7488. (b) Paolucci, C.; Mazzini, C.; Fava, A. J . Org. Chem 1995, 60, 169. (c) Ottolina, G.; Carrea, G.; Colonna, S.; Ruckemann, A. Tetrahedron: Asymmetry 1996, 7, 1123. (d) Kayser, M. M.; Chen, G.; Stewart, J . D. J . Org. Chem. 1998, 63, 7103. 
talysis of samarium ion and mercaptan. This transformation involves a sequential acetalization, Tishchenko reaction, and lactonization in a one-pot procedure. The deliberative use of mercaptan is advantageous to facilitate the catalytic cycle (Figure 2). For example, 5-oxo-5pentanal (1a) was converted to 5-phenylpentanolide (2a) in a quantitative yield by using $20 \mathrm{~mol} \%$ of $\mathrm{Sml}_{2}$ and 10 mol \% of i-PrSH as the promoters (entry 4, Table 1). The active catalyst may be considered as RS-Sml. Thus, $\mathrm{Sml}_{2} / \mathrm{RSSR}$ and $\mathrm{Sml}_{3} / \mathrm{PhSL} i$ can replace $\mathrm{Sml}_{2} / \mathrm{i}-\mathrm{PrSH}$ to promote the transformation of 5-oxoalkanals to their corresponding $\delta$-lactones (Table 2). This approach to $\delta$-lactones adapts the atom economy of intramolecular redox process, unlike the conventional methods requiring excess amounts of oxidizing and reducing agents to convert 5-oxoalkanals into 5-hydroxyalkanoic acid for the subsequent lactonization.

The $\mathrm{Sml}_{2} / \mathrm{i}$-PrSH-promoted reactions of 2-methyl-, 3-methyl-, and 4-methyl-5-oxoalkanals occurred in a high stereoselective manner. The stereochemistry can be explained by the favorable transition states $\mathbf{C}$ and $\mathbf{E}$ (Figure 3). We have also utilized the remote control of such samarium-ion-catalyzed reactions to synthesize optically active $\delta$-lactones via three routes, by using chiral substituted-5-oxoaldehydes (eq 2), stoichiometric amount of chiral alcohols (Table 4), and catalytic amount of chiral mercaptan (Scheme 4). Thus, enantiomerically pure (2S,5R)-2-methylhexanolide (10), (S)-enriched 5-phenylpentanolide (2a, 78\% ee), and (R)-enriched hexadecanolide (2j, 74\% ee) were synthesized from their corresponding 5-oxoalkanals practically in one-pot procedures. The synthesis of insect pheromones 2j and $\mathbf{1 0}$ also demonstrates a new protocol for asymmetric reduction of long-chain aliphatic ketones.

\section{Experimental Section}

General. All reactions requiring anhydrous conditions were conducted in flame-dried apparatus under an atmosphere of argon or nitrogen. Syringes and needles for the transfer of reagents were dried at $100{ }^{\circ} \mathrm{C}$ and allowed to cool in a desiccator over $\mathrm{P}_{2} \mathrm{O}_{5}$ before use. Ethers were distilled from sodium benzophenone ketyl; (chlorinated) hydrocarbons, and amines from $\mathrm{CaH}_{2}$. Reactions were monitored by TLC precoated with a $0.25 \mathrm{~mm}$ layer of silica gel containing a fluorescent indicator (Merck Art. 5544). Column chromatography was carried out on Kieselgel 60 (40-63 $\mu \mathrm{m})$. HPLC was performed on Lichrosorb Si 60 and Nucleosil 100 columns (25 $\mathrm{cm} \times 1 \mathrm{~cm}$ i.d.) with particle size of $7 \mu \mathrm{m}$. Chiracel OB, OB-H, and OD columns ( $25 \mathrm{~cm} \times 0.46 \mathrm{~cm}$ i.d.) were used for analysis of enantiomeric excesses. Refractive index or UV detectors were used. Melting points are uncorrected. Optical rotations were measured on a digital polarimeter with a cuvette of 10 $\mathrm{cm}$ length. $[\alpha]_{D}$ values are given in $10^{-1} \mathrm{deg} \mathrm{cm} \mathrm{cm}^{-1}$. Chemical shifts of ${ }^{1} \mathrm{H}$ and ${ }^{13} \mathrm{C}$ NMR spectra are reported relative to $\mathrm{CHCl}_{3}\left[\delta_{\mathrm{H}} 7.24, \delta_{\mathrm{C}}\right.$ (central line of t) 77.0]. Coupling constants (J) are given in hertz $(\mathrm{Hz})$. Distortionless enhancement pol arization transfer (DEPT) spectra were taken to determine the types of carbon signals. The X-ray diffraction data were collected on a CAD-4 diffractometer. The analyses were carried out on a microVAX III computer using NRC VAX software.

Representative Procedure for the Preparation of 5-Oxoalkanals (Scheme 1).

Method A. ${ }^{12}$ Under an atmosphere of $\mathrm{N}_{2}$, an ethereal solution $(20 \mathrm{~mL})$ of Grignard reagent was prepared from bromobenzene $(6.0 \mathrm{~g}, 38 \mathrm{mmol})$ and $\mathrm{Mg}(960 \mathrm{mg}, 40 \mathrm{mmol})$ by the activation of $\mathrm{I}_{2}$ (small amount). A solution of cyclopentanone $(2.5 \mathrm{~g}, 30 \mathrm{mmol})$ in $\mathrm{Et}_{2} \mathrm{O}(10 \mathrm{~mL})$ was added dropwise at room temperature $\left(25^{\circ} \mathrm{C}\right)$. The mixture was stirred for $2 \mathrm{~h}$ and then poured into an ice-cold $1 \mathrm{~N} \mathrm{HCl}$ solution $(60 \mathrm{~mL})$.
The mixture was extracted with $\mathrm{Et}_{2} \mathrm{O}(3 \times)$. The ethereal phase was combined, washed with brine $(3 \times)$, dried $\left(\mathrm{Na}_{2} \mathrm{SO}_{4}\right)$, and concentrated to give a crude addition product.

The crude product was dissolved into benzene $(30 \mathrm{~mL})$, and $\mathrm{p}-\mathrm{TsOH}(20 \mathrm{mg})$ was added. The mixture was heated at reflux for $8 \mathrm{~h}$ while the generated water was removed azeotropically via Dean-Stark equipment. The mixture was concentrated and purified on a silica gel column by elution with hexane to give al kene $(4.0 \mathrm{~g}, 93 \%)$.

The al kene was dissolved into $\mathrm{CH}_{2} \mathrm{Cl}_{2}(40 \mathrm{~mL})$, and a stream of ozone passed through the solution at $-78^{\circ} \mathrm{C}$ until the light blue col or of ozone persisted. The solution was purged with $\mathrm{N}_{2}$, and stirred at room temperature for $10 \mathrm{~min}$. The mixture was stirred with $\mathrm{Me}_{2} \mathrm{~S}(5 \mathrm{~mL})$ for $5 \mathrm{~h}$, followed by addition of $\mathrm{Ph}_{3} \mathrm{P}$ in portions $(4 \times 1 \mathrm{~g})$. The mixture was stirred for $5 \mathrm{~h}$, concentrated, and purified on a silica gel column by elution with EtOAc/hexane (1:4) to give 5-oxo-5-phenyl pentanal (1a, $4.3 \mathrm{~g}, 88 \%$ ).

Method B. ${ }^{13} \mathrm{~A}$ mixture of pinacolone $(3.0 \mathrm{~g}, 30 \mathrm{mmol})$ and 1,1-dimethylhydrazine $(3.6 \mathrm{~g}, 60 \mathrm{mmol})$ was heated at reflux for $10 \mathrm{~h}$. Distillation using Kugel rohr apparatus gave hydrazone product $(3.80 \mathrm{~g}, 89 \%)$.

To a solution of the hydrazone product $(1.0 \mathrm{~g}, 7.2 \mathrm{mmol})$ in THF (10 mL) was added dropwise BuLi $(6.0 \mathrm{~mL}$ of $1 \mathrm{M}$ solution in hexane) at $0{ }^{\circ} \mathrm{C}$. The mixture was stirred for $30 \mathrm{~min}$, and 4-bromo-1-butene (1.29 g, $9.6 \mathrm{mmol}$ ) was added dropwise. The mixture was stirred at room temperature for $10 \mathrm{~h}$, quenched by addition of water $(5 \mathrm{~mL})$, and extracted with EtOAc $(2 \times)$. The organic phase was concentrated, after which acetone (20 $\mathrm{mL}$ ) and acidic resin (Amberlyte IR 120, ca. $2 \mathrm{~g}$ ) were added. The mixture was stirred for $9 \mathrm{~h}$, concentrated, and chromatographed on a silica gel column by elution with EtOAc/hexane (5:95) to give alkene product (762 mg, 69\%). Ozonation by a procedure similar to that for la gave 6,6-dimethyl-5-oxoheptanal (1h, $241 \mathrm{mg}$, 97\%).

Method C. ${ }^{14}$ Isobutyral dehyde $(2.37 \mathrm{~g}, 32.9 \mathrm{mmol})$ was added to a mixture of $\mathrm{Me}_{3} \mathrm{SiCl}(5.23 \mathrm{~g}, 49.3 \mathrm{mmol})$ and $\mathrm{Et}_{3} \mathrm{~N}$ $(6.6 \mathrm{~g}, 65.8 \mathrm{mmol})$ in DMF $(20 \mathrm{~mL})$. The mixture was heated at reflux for $4 \mathrm{~h}$, cooled, diluted with hexane $(40 \mathrm{~mL})$, and washed with cold aqueous $\mathrm{NaHCO}_{3}$ solution $(3 \times)$. The organic phase was dried $\left(\mathrm{Na}_{2} \mathrm{SO}_{4}\right)$ and distilled at $70{ }^{\circ} \mathrm{C}$ to give the corresponding silyl enol ether $(4.10 \mathrm{~g}, 87 \%)$.

A mixture of the silyl enol ether $(1.02 \mathrm{~g}, 7.1 \mathrm{mmol})$ and methyl vinyl ketone $(840 \mathrm{mg}, 12 \mathrm{mmol})$ was added to a suspension of $\mathrm{Al}_{2} \mathrm{O}_{3}(5.00 \mathrm{~g})$ and $\mathrm{ZnCl}_{2}(1.35 \mathrm{~g})$ in $\mathrm{Et}_{2} \mathrm{O}(30$ $\mathrm{mL}$ ) at $0{ }^{\circ} \mathrm{C}$. The mixture was stirred for $30 \mathrm{~min}$, after which $\mathrm{BF}_{3} \cdot \mathrm{OEt}_{2}(1.5 \mathrm{~mL})$ was added. The mixture was stirred at 0 ${ }^{\circ} \mathrm{C}$ for $4 \mathrm{~h}$, and quenched by addition of water $(1 \mathrm{~mL})$. Chromatography on a short silica gel column by elution with EtOAc/hexane (1:4) gave 2,2-dimethyl-5-oxohexanal (1i, 992 mg, 99\%).

Representative Procedure for Transformation of 5-Oxoalkanals to $\delta$-Lactones (Schemes 2, 3 and 4). Method D. Under an atmosphere of argon, i-PrSH (30 mg, $0.04 \mathrm{~mL}, 0.4 \mathrm{mmol}$ ) was added to a deep blue $\mathrm{Sml}_{2}(0.5 \mathrm{mmol})$ solution freshly prepared from samarium (80 mg) and 1,2diiodoethane $(140 \mathrm{mg})$ in THF $(15 \mathrm{~mL})$. The mixture was stirred for $5 \mathrm{~min}$ at room temperature, and a THF solution (5 $\mathrm{mL}$ ) of 5-oxo-5-phenylpentanal (1a, $176 \mathrm{mg}, 1.0 \mathrm{mmol}$ ) was added dropwise. The mixture was stirred for $1 \mathrm{~h}$, and then filtered through a short silica gel column by elution with EtOAc/hexane (1:1). The filtrate was concentrated by rotary evaporation to give a practically pure lactone 2 a (174 mg, 99\%).

Method E. A slightly modified procedure was conducted by premixing an aliquot of Sml $/ \mathrm{i}-\mathrm{PrSH}$ (ca. $3 \mathrm{~mol} \%$ in $1 \mathrm{~mL}$ of THF) with the THF solution (5 mL) of 5-oxohexanal (1), $114 \mathrm{mg}, 1.0 \mathrm{mmol}$ ) in an oven-dried syringe. The resulting yellow solution, an indicator of trivalent samarium ion, was then added dropwise to the original $\mathrm{Sml}_{2} / \mathrm{i}-\mathrm{PrSH}(50 / 40 \mathrm{~mol}$ $\%)$ solution in THF (14 mL). Accordingly, the desired product 5-hexanolide (2b, $133 \mathbf{m g}$ ) was also obtained in an excellent yield (99\%).

By a similar procedure, chiral mercaptans were used to replace i-PrSH in the enantioselective reactions (Scheme 4 and Table 5). 
Representative Procedure for the Reactions of 5-Oxoalkanals with Chiral Alcohols Promoted by $\mathrm{Sml}_{2}$ or $\mathrm{Sml}_{3}$ (Table 4). Method F. A solution of 5-oxo-5-phenylpentanal ( $88 \mathrm{mg}, 0.5 \mathrm{mmol}$ ) and (-)-menthol (79 $\mathrm{mg}, 0.5 \mathrm{mmol}$ ) in THF (10 $\mathrm{mL})$ was added to the freshly prepared $\mathrm{Sml}_{2}(5 \mathrm{~mL}$ of 0.1 $\mathrm{M}$ solution in THF). The mixture was stirred for $1 \mathrm{~h}$ at room temperature, and filtered through a short silica gel column by elution with EtOAc/hexane (1:1). The filtrate was concentrated to give a mixture of lactone $\mathbf{2 a}$, hydroxyester $\mathbf{1 2} \mathbf{a}$, and diester $13 \mathbf{a}$ in a ratio of 61:31:8 as indicated by the ${ }^{1} \mathrm{H}$ NMR analysis. Hydroxyester 12a was further separated by chromatography with elution of EtOAc/hexane (1:9). Saponification of $\mathbf{1 2 a}$, followed by acidification, gave lactone $\mathbf{2 a}$ with $84 \%$ ee in favor of the (S)-enantiomer as determined by HPLC analysis on a Chiralcel OB column.

Method G. A solution of $\mathrm{Sml}_{3}$ was prepared from Sm (150 $\mathrm{mg}, 1 \mathrm{mmol})$ and $\mathrm{I}_{2}(390 \mathrm{mg}, 1.5 \mathrm{mmol})$ in THF (1.5 mL). An al iquot of $\mathrm{Sml}_{3}$ solution $(0.15 \mathrm{~mL}, 0.15 \mathrm{mmol})$ was taken, and the reaction of 5-oxo-5-phenylpentanal (100 mg, $0.57 \mathrm{mmol}$ ) and $(-)$-menthol $(95 \mathrm{mg}, 0.61 \mathrm{mmol}$ ) was conducted in refluxing THF $(10 \mathrm{~mL})$ for $1 \mathrm{~h}$. The crude product was treated with trifluoroacetic acid $(0.5 \mathrm{~mL})$ in $\mathrm{CH}_{2} \mathrm{Cl}_{2}(10 \mathrm{~mL})$ at $0{ }^{\circ} \mathrm{C}$ for $3 \mathrm{~h}$ to give lactone $\mathbf{2 a}$ (65 mg, 65\% yield) with $78 \%$ ee in favor of the (S)-enantiomer.

5-Phenyl-5-pentanolide (2a). ${ }^{31}$ Solid, mp 91-93 ${ }^{\circ} \mathrm{C}$; HPLC (Chiralcel OB column) $t_{R}(S) / t_{R}(R)=13.4 \mathrm{~min} / 15.9 \mathrm{~min}$, eluent $10 \%$ i-PrOH in hexane, flow rate $2 \mathrm{~mL} / \mathrm{min}$ (UV $254 \mathrm{~nm}$ ). $[\alpha]^{26}{ }_{\mathrm{D}}$ $=-19.1$ ( $\mathrm{c}=0.9, \mathrm{CHCl}_{3}, 49 \%$ ee in favor of the S-enantiomer).

5-Hexanolide (2b). ${ }^{44}$ HPLC (Chiralcel OB column) $t_{R}(\mathrm{~S}) /$ $t_{R}(R)=11.0 \mathrm{~min} / 14.3 \mathrm{~min}$, eluent $10 \% \mathrm{i}-\mathrm{PrOH}$ in hexane, flow rate $2 \mathrm{~mL} / \mathrm{min}$ (UV $225 \mathrm{~nm}$ ). $[\alpha]^{29}{ }_{\mathrm{D}}=+14.8$ (c $=0.3, \mathrm{CHCl}_{3}$, $47 \%$ ee in favor of the R-enantiomer)

5-Heptanolide (2c)..$^{45}$ By a procedure similar to that for 2b (Method E), 5-oxoheptanal (1c, $170 \mathrm{mg}, 1.3 \mathrm{mmol}$ ) was treated with $\mathrm{Sml}_{2} / \mathrm{i}-\mathrm{PrSH}(0.5 \mathrm{mmol} / 0.4 \mathrm{mmol})$ at room temperature to give the title compound 2c (155 mg, 91\%).

5-Undecanolide (2d). ${ }^{29 b}$ By a procedure similar to that for 2b (Method E), 5-oxoundecanal (1d, $184 \mathrm{mg}, 1.0 \mathrm{mmol}$ ) was treated with $\mathrm{Sml} / \mathrm{i}-\mathrm{PrSH}(0.5 \mathrm{mmol} / 0.4 \mathrm{mmol})$ at room temperature to give the title compound $\mathbf{2 d}$ (182 mg, 99\%). HPLC (Chiralcel OB-H column) $t_{R}(S) / t_{R}(R)=15.5 \mathrm{~min} / 16.9 \mathrm{~min}$, eluent $5 \% \mathrm{i}-\mathrm{PrOH}$ in hexane, flow rate $1 \mathrm{~mL} / \mathrm{min}$ (RI detector). $[\alpha]^{24}=+18.6\left(\mathrm{c}=0.9, \mathrm{CHCl}_{3}, 40 \%\right.$ ee in favor of the R-enantiomer).

5-Tridecanolide (2e). ${ }^{32}$ By a procedure similar to that for 2b (Method E), 5-oxotridecanal (1e, $220 \mathrm{mg}, 1.0 \mathrm{mmol}$ ) was treated with $\mathrm{Sml} / 2 / \mathrm{i}-\mathrm{PrSH}(0.5 \mathrm{mmol} / 0.4 \mathrm{mmol})$ at room temperature to give the title compound 2 e (207 $\mathrm{mg}, 94 \%)$. Solid, $\mathrm{mp} 42-43{ }^{\circ} \mathrm{C}$; HPLC (Chiralcel OB-H column) $t_{R}(S) / t_{R}(R)=$ $8.7 \mathrm{~min} / 11.2 \mathrm{~min}$, eluent $5 \% \mathrm{i}-\mathrm{PrOH}$ in hexane, flow rate 1.0 $\mathrm{mL} / \mathrm{min}$ (UV $225 \mathrm{~nm}$ or RI detector). $[\alpha]^{27} \mathrm{D}=+22.0$ (c $=0.7$, $\mathrm{CHCl}_{3}, 68 \%$ ee in favor of the R-enantiomer).

5-Phenyl-5-hexanolide (2f). ${ }^{46}$ By a procedure similar to that for $\mathbf{2 b}$ (M ethod E), 5-oxo-6-phenylhexanal (1f, $97 \mathrm{mg}, 0.5$ $\mathrm{mmol}$ ) was treated with $\mathrm{Sml} / 2 / \mathrm{i}-\mathrm{PrSH}(0.25 \mathrm{mmol} / 0.23 \mathrm{mmol})$ at room temperature to give the title compound $\mathbf{2 f}(96 \mathrm{mg}$, 99\%). HPLC (Chiralcel OB column) $t_{R}$ (minor isomer)/ $t_{R}$ (major isomer) $=12.0 \mathrm{~min} / 13.3 \mathrm{~min}$, eluent $10 \% \mathrm{i}-\mathrm{PrOH}$ in hexane, flow rate $1 \mathrm{~mL} / \mathrm{min}$ (UV $254 \mathrm{~nm}$ ). $[\alpha]^{30} \mathrm{D}=+7.7\left(\mathrm{c}=0.5, \mathrm{CHCl}_{3}\right.$ $48 \%$ ee in favor of the less retained enantiomer).

5-Cyclohexyl-5-pentanolide (2g). ${ }^{47}$ By a procedure similar to that for $\mathbf{2 b}$ (Method E), 5-oxo-5-cyclohexylpentanal ( $\mathbf{l g}$, $49 \mathrm{mg}, 0.27 \mathrm{mmol}$ ) was treated with $\mathrm{Sml} / 2 / \mathrm{i}-\mathrm{PrSH}(0.25 \mathrm{mmol} /$

(44) White, J . D.; Somers, T. C.; Reddy, G. N. J . Am. Chem. Soc. 1986, 108,5352

(45) (a) Soai, K.; Yokoyama, S.; Hayasaka, T.; Ebihara, K. Chem. Lett. 1988, 843. (b) Sato, M.; Sugita, Y. A.; Kaneko, C. Tetrahedron: Asymmetry 1992, 3, 1157 .

(46) J ones, J . B. J . Org. Chem. 1979, 44, 2165

(47) Otsubo, K.; Kawamura, K.; Inanaga, J .; Yamaguchi, M. Chem. Lett. 1987, 1487.

(48) Garner, P.; Anderson, J . T. Tetrahedron Lett. 1997, 38, 6647. 3291.

(49) Souma, Y., I yoda, J .; Sano, H. Bull. Chem. Soc. J pn. 1976, 49,

(50) J etter, R.; Riederer, M. Phytochemistry 1999, 50, 1359.
$0.23 \mathrm{mmol}$ ) at room temperature to give the title compound 2 g (47 mg, 96\%). Solid, mp 47-49 ${ }^{\circ} \mathrm{C}$; HPLC (Chiralcel OD column) $t_{R}$ (minor isomer) $/ t_{R}$ (major isomer) $=9.1 \mathrm{~min} / 10.3 \mathrm{~min}$, eluent $5 \% \mathrm{i}-\mathrm{PrOH}$ in hexane, flow rate $1.3 \mathrm{~mL} / \mathrm{min}$ (UV 225 $\mathrm{nm}) .[\alpha]^{29}{ }_{\mathrm{D}}=-11.3\left(\mathrm{c}=1.0, \mathrm{CHCl}_{3}, 43 \%\right.$ ee in favor of the more retained enantiomer).

6,6-Dimethyl-5-heptanolide ( $2 \mathrm{~h}){ }^{48}$ By a procedure similar to that for $\mathbf{2 b}$ (Method E), 6,6-dimethyl-5-oxoheptanal (1h, $181 \mathrm{mg}, 1.2 \mathrm{mmol}$ ) was treated with $\mathrm{Sml} / \mathrm{i}-\mathrm{PrSH}(0.50 \mathrm{mmol} /$ $0.34 \mathrm{mmol}$ ) at room temperature to give the title compound 2h (165 mg, 91\%). HPLC (Chiralcel OB column) $t_{R}$ (minor isomer) $/ \mathrm{t}_{\mathrm{R}}$ (major isomer) $=9.9 \mathrm{~min} / 11.0 \mathrm{~min}$, eluent $5 \% \mathrm{i}-\mathrm{PrOH}$ in hexane, flow rate $1.5 \mathrm{~mL} / \mathrm{min}$ (UV $225 \mathrm{~nm}$ ). $[\alpha]^{30} \mathrm{D}=-12.0$ (c $=0.3, \mathrm{CHCl}_{3}, 44 \%$ ee in favor of the more retained enantiomer).

2,2-Dimethyl-5-hexanolide (2i). ${ }^{49}$ By a procedure similar to that for $\mathbf{2 b}$ (Method E), 2,2-dimethyl-5-oxohexanal (1i, 58 $\mathrm{mg}, 0.41 \mathrm{mmol})$ was treated with $\mathrm{Sml} / \mathrm{i}-\mathrm{PrSH}(0.17 \mathrm{mmol} /$ $0.15 \mathrm{mmol}$ ) at room temperature to give the title compound 2i (46 mg, 80\%).

5-Hexadecanolide (2j). ${ }^{43}$ By a procedure similar to that for $\mathbf{2 b}$ (Method E), 5-oxo-hexadecanal (1j, $51 \mathrm{mg}, 0.20 \mathrm{mmol}$ ) was treated with $\mathrm{Sml} / \mathrm{i}-\mathrm{PrSH}(0.15 \mathrm{mmol} / 0.13 \mathrm{mmol})$ at room temperature to give the title compound $\mathbf{2 j}$ ( $43 \mathrm{mg}, 85 \%)$. Sol id, $\mathrm{mp} 39-40{ }^{\circ} \mathrm{C}$; HPLC (Chiralcel OB-H column) $t_{R}(S) / t_{R}(R)=$ $21.9 \mathrm{~min} / 23.3 \mathrm{~min}$, eluent $1.25 \% \mathrm{i}-\mathrm{PrOH}$ in hexane, flow rate $0.5 \mathrm{~mL} / \mathrm{min}$ (RI detector). $[\alpha]_{\mathrm{D}}^{26}=+27.9$ (c $=0.5$, THF , 74\% ee in favor of the R-enantiomer).

5-Nonadecanolide (2k). By a procedure similar to that for $\mathbf{2 b}$ (Method E), 5-oxononadecanal (1k, $110 \mathbf{~ m g}, 0.37 \mathrm{mmol}$ ) was treated with $\mathrm{Sml} / \mathrm{i}-\mathrm{PrSH}(0.40 \mathrm{mmol} / 0.30 \mathrm{mmol})$ at room temperature to give the title compound $\mathbf{2 k}(84 \mathrm{mg}, 76 \%)$. Solid, $\mathrm{mp} 49-51^{\circ} \mathrm{C}$; TLC [EtOAc/hexane $\left.(20: 80)\right] \mathrm{R}_{\mathrm{f}}=0.40$; I R (neat) $1725 \mathrm{~cm}^{-1}$; ${ }_{1} \mathrm{H}$ NMR $\left(\mathrm{CDCl}_{3}, 200 \mathrm{MHz}\right) \delta 0.85(3 \mathrm{H}$, br t, J = $6.1 \mathrm{~Hz}), 1.23(20 \mathrm{H}$, br s), 1.51-1.71 $(4 \mathrm{H}, \mathrm{m}), 1.75-1.93(2 \mathrm{H}$, $\mathrm{m}), 2.41-2.56(2 \mathrm{H}, \mathrm{m}), 4.18-4.28(1 \mathrm{H}, \mathrm{m}) ;{ }^{13} \mathrm{C} \mathrm{NMR}\left(\mathrm{CDCl}_{3}\right.$, $50 \mathrm{MHz}) \delta 14.0\left(\mathrm{CH}_{3}\right), 18.5\left(\mathrm{CH}_{2}\right), 22.6\left(\mathrm{CH}_{2}\right), 24.9\left(\mathrm{CH}_{2}\right), 27.8$ $\left(\mathrm{CH}_{2}\right), 29.3\left(\mathrm{CH}_{2}\right), 29.37\left(\mathrm{CH}_{2}\right), 29.4\left(\mathrm{CH}_{2}\right), 29.5\left(\mathrm{CH}_{2}\right), 29.6$ $\left(\mathrm{CH}_{2}\right), 31.9\left(\mathrm{CH}_{2}\right), 35.8\left(\mathrm{CH}_{2}\right), 80.6(\mathrm{CH}), 171.9(\mathrm{C})$. HR-FABMS calcd for $\mathrm{C}_{19} \mathrm{H}_{37} \mathrm{O}_{2}\left(\mathrm{M}^{+}+1\right)$ : 297.2794. Found: 297.2793 . HPLC (Chiralcel OB-H column) $t_{R}$ (minor isomer)/ $t_{R}$ (major isomer) $=18.6 \mathrm{~min} / 20.1 \mathrm{~min}$, eluent $1.25 \% \mathrm{i}-\mathrm{PrOH}$ in hexane, flow rate $0.8 \mathrm{~mL} / \mathrm{min}$ (RI detector). $[\alpha]^{25} \mathrm{D}=+16.0$ (c $=1.5$, $\mathrm{CHCl}_{3}, 63 \%$ ee in favor of the more retained enantiomer).

5-Tricosanolide (2l). ${ }^{50}$ By a procedure similar to that for 2b (Method E), 5-oxotricosanal (1l, $170 \mathrm{mg}, 0.48 \mathrm{mmol}$ ) was treated with $\mathrm{Sml} / \mathrm{i}-\mathrm{PrSH}(0.30 \mathrm{mmol} / 0.25 \mathrm{mmol})$ at room temperature to give the title compound $\mathbf{2 l}$ (146 mg, 86\%). Solid, $\mathrm{mp}$ 56-57 ${ }^{\circ} \mathrm{C}$; HPLC (Chiralcel OB-H column) $\mathrm{t}_{\mathrm{R}}$ (minor isomer) $/ \mathrm{t}_{\mathrm{R}}$ (major isomer) $=19.9 \mathrm{~min} / 22.1 \mathrm{~min}$, eluent $1.25 \%$ $\mathrm{i}-\mathrm{PrOH}$ in hexane, flow rate $0.8 \mathrm{~mL} / \mathrm{min}$ (RI detector). $[\alpha]^{25} \mathrm{D}$ $=+10.2$ ( $\mathrm{c}=3.0, \mathrm{CHCl}_{3}, 65 \%$ ee in favor of the more retained enantiomer).

5-(2-Methoxyphenyl)-5-pentanolide (2m). By a procedure similar to that for $\mathbf{2 b}$ (Method E), 5-(2-methoxyphenyl)5-oxopentanal (1m, $206 \mathrm{mg}, 1.0 \mathrm{mmol}$ ) was treated with $\mathrm{Sml}_{2} /$ i-PrSH $(0.50 \mathrm{mmol} / 0.40 \mathrm{mmol})$ at room temperature to give the title compound $\mathbf{2 m}$ (176 $\mathrm{mg}, 85 \%)$. Solid, $\mathrm{mp} 79-81{ }^{\circ} \mathrm{C}$; TLC [EtOAc/hexane (50:50)] $\mathrm{R}_{\mathrm{f}}=0.33$; IR (neat) $1726 \mathrm{~cm}^{-1}$; ${ }^{1} \mathrm{H} \mathrm{NMR}\left(\mathrm{CDCl}_{3}, 200 \mathrm{MHz}\right) \delta 1.70-1.86(1 \mathrm{H}, \mathrm{m}), 1.89-1.98$ $(2 \mathrm{H}, \mathrm{m}), 2.14-2.20(1 \mathrm{H}, \mathrm{m}), 2.49-2.74(2 \mathrm{H}, \mathrm{m}), 3.87(3 \mathrm{H}$, s), $5.67(1 \mathrm{H}, \mathrm{dd}, \mathrm{J}=10.1 \mathrm{~Hz}, \mathrm{~J}=3.5 \mathrm{~Hz}), 6.83-7.00(3 \mathrm{H}$, $\mathrm{m}), 7.22-7.38(2 \mathrm{H}, \mathrm{m}) ;{ }^{13} \mathrm{C} \mathrm{NMR}\left(\mathrm{CDCl}_{3}, 50 \mathrm{MHz}\right) \delta 18.5$ $\left(\mathrm{CH}_{3}\right), 28.9\left(\mathrm{CH}_{2}\right), 29.7\left(\mathrm{CH}_{2}\right), 55.3\left(\mathrm{CH}_{3}\right), 76.9(\mathrm{CH}), 110.3$ $(\mathrm{CH}), 120.7(\mathrm{CH}), 126.4(\mathrm{CH}), 128.1(\mathrm{C}), 128.9(\mathrm{CH}), 155.6(\mathrm{C})$ 171.8 (C). HR-FAB-MS calcd for $\mathrm{C}_{12} \mathrm{H}_{15} \mathrm{O}_{3}\left(\mathrm{M}^{+}+1\right)$ : 207.1021 . Found: 207.1017. HPLC (Chiralcel OB column) $t_{R}$ (major isomer $) / t_{R}($ minor isomer $)=10.9 \mathrm{~min} / 13.5 \mathrm{~min}$, eluent $20 \%$ $\mathrm{i}-\mathrm{PrOH}$ in hexane, flow rate $2 \mathrm{~mL} / \mathrm{min}(254 \mathrm{~nm})$. $[\alpha]^{24} \mathrm{D}=-9.4$ ( $\mathrm{C}=1.5, \mathrm{CHCl}_{3}, 49 \%$ ee in favor of the less retained enantiomer).

4-Methyl-5-heptanolide (8a). ${ }^{19}$ By a procedure similar to that for $\mathbf{2 b}$ (Method E), 4-methyl-5-oxoheptanal (4a, $160 \mathrm{mg}$, $1.23 \mathrm{mmol}$ ) was treated with $\mathrm{Sml} / \mathrm{i}-\mathrm{PrSH}(0.50 \mathrm{mmol} / 0.43$ $\mathrm{mmol}$ ) at room temperature to give the title compound $\mathbf{8 a}$ (cis 
isomer, $155 \mathrm{mg}, 91 \%) .{ }^{1} \mathrm{H} \mathrm{NMR}\left(\mathrm{CDCl}_{3}, 200 \mathrm{MHz}\right) \delta 0.91$ (3 $\mathrm{H}, \mathrm{t}, \mathrm{J}=6.7 \mathrm{~Hz}), \delta 0.96(3 \mathrm{H}, \mathrm{d}, \mathrm{J}=7.4 \mathrm{~Hz}), 1.44-1.72(3 \mathrm{H}$, m), $1.90-2.05(2 \mathrm{H}, \mathrm{m}), 2.47(2 \mathrm{H}, \mathrm{t}, \mathrm{J}=7.6 \mathrm{~Hz}), 4.14(1 \mathrm{H}$, ddd, J $=11.5 \mathrm{~Hz}$, J $=5.5 \mathrm{~Hz}$, J $=2.8 \mathrm{~Hz}$ ).

4-Methyl-5-phenyl-5-pentanolide (8b). ${ }^{20}$ By a procedure similar to that for $\mathbf{2 b}$ (Method E), 4-methyl-5-oxo-5-phenylpentanal (4b, $61 \mathrm{mg}, 0.32 \mathrm{mmol}$ ) was treated with $\mathrm{Sml} / \mathrm{i}-\mathrm{PrSH}$ ( $0.25 \mathrm{mmol} / 0.17 \mathrm{mmol})$ at room temperature to give the title

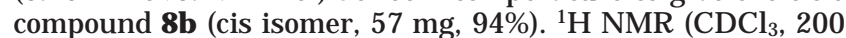
$\mathrm{MHz}) \delta 0.76(3 \mathrm{H}, \mathrm{d}, \mathrm{J}=6.1 \mathrm{~Hz}), 1.68-1.81(1 \mathrm{H}, \mathrm{m}), 2.10-$ $2.31(2 \mathrm{H}, \mathrm{m}), 2.67(2 \mathrm{H}, \mathrm{dd}, \mathrm{J}=7.2 \mathrm{~Hz}, \mathrm{~J}=6.7 \mathrm{~Hz}), 5.48(1$ $\mathrm{H}, \mathrm{d}, \mathrm{J}=3.0 \mathrm{~Hz}), 7.13-7.36(5 \mathrm{H}, \mathrm{m})$.

3-Methyl-5-phenyl-5-pentanolide (9a). ${ }^{21}$ By a procedure similar to that for $\mathbf{2 b}$ (Method E), 3-methyl-5-oxo-5-phenylpentanal $(5 \mathbf{a}, 94 \mathrm{mg}, 0.48 \mathrm{mmol}$ ) was treated with $\mathrm{Sml} / 2 / \mathrm{i}-\mathrm{PrSH}$ $(0.50 \mathrm{mmol} / 0.43 \mathrm{mmol})$ at room temperature to give the title compound 9a (91 mg, 97\%) as a mixture of trans and cis isomers (77:23). The isomeric ratio changed to trans/cis $=94: 6$ when the reaction was conducted at $0{ }^{\circ} \mathrm{C}$. trans-9a: ${ }^{1} \mathrm{H}$ NMR $\left(\mathrm{CDCl}_{3}, 200 \mathrm{MHz}\right) \delta 1.09(3 \mathrm{H}, \mathrm{d}, \mathrm{J}=6.2 \mathrm{~Hz}), 1.82-1.88(1 \mathrm{H}$, $\mathrm{m}), 2.02-2.31(3 \mathrm{H}, \mathrm{m}), 2.68(1 \mathrm{H}, \mathrm{dd}, \mathrm{J}=16.3 \mathrm{~Hz}, \mathrm{~J}=5.3$ $\mathrm{Hz}), 5.50(1 \mathrm{H}, \mathrm{dd}, \mathrm{J}=7.3 \mathrm{~Hz}, \mathrm{~J}=4.6 \mathrm{~Hz}), 7.27-7.36(5 \mathrm{H}$, m). cis-9a: ${ }^{1} \mathrm{H} N M R\left(\mathrm{CDCl}_{3}, 400 \mathrm{MHz}\right) \delta 1.07(3 \mathrm{H}, \mathrm{d}, \mathrm{J}=6.4$ $\mathrm{Hz}), 1.49-1.56(1 \mathrm{H}, \mathrm{m}), 2.12-2.19(3 \mathrm{H}, \mathrm{m}), 2.79(1 \mathrm{H}, \mathrm{dd}, \mathrm{J}$ $=11.9,1.9 \mathrm{~Hz}), 5.29(1 \mathrm{H}, \mathrm{dd}, \mathrm{J}=12.0,3.1 \mathrm{~Hz}), 7.30-7.38(5$ $\mathrm{H}, \mathrm{m})$.

(3S,5S)-3-Methyl-5-hexanolide (9b) ${ }^{24}$ and (2R,5S)-2Methyl-5-hexanolide (10) ${ }^{25}$. By a procedure similar to that for $\mathbf{2 b}$ (Method E), a mixture of 3-methyl-5-oxohexanal (5b) and 2-methyl-5-oxohexanal (6) $(1: 1,128 \mathrm{mg}, 1.0 \mathrm{mmol})$ was treated with $\mathrm{Sml} / \mathrm{i}-\mathrm{PrSH}(0.5 \mathrm{mmol} / 0.4 \mathrm{mmol})$ at $0{ }^{\circ} \mathrm{C}$ to give a mixture of $(3 S, 5 S)-9 b$ and $(2 R, 5 S)-10$ (1:1). The analytic samples were isol ated by HPLC with elution of EtOAc/hexane (3:7). (3S,5S)-9b: $[\alpha]^{25} \mathrm{D}=-57.7(\mathrm{c}=0.1, \mathrm{MeOH}) ;{ }^{13} \mathrm{C} N \mathrm{NR}$ $\left(\mathrm{CDCl}_{3}, 125 \mathrm{MHz}\right) \delta 21.3,21.4,23.7,36.6,37.3,73.6,172.4$. $(2 \mathrm{R}, 5 \mathrm{~S})-10:[\alpha]^{25} \mathrm{D}=-82.5\left(\mathrm{c}=0.6, \mathrm{CHCl}_{3}\right) ;{ }^{1} \mathrm{H} \mathrm{NMR}\left(\mathrm{CDCl}_{3}\right.$, $500 \mathrm{MHz}) \delta 1.20(3 \mathrm{H}, \mathrm{d}, \mathrm{J}=6.8 \mathrm{~Hz}), 1.34(3 \mathrm{H}, \mathrm{d}, \mathrm{J}=6.2$ $\mathrm{Hz}), 1.49-1.64(2 \mathrm{H}, \mathrm{m}), 1.87-1.93(1 \mathrm{H}, \mathrm{m}), 2.02-2.10(1 \mathrm{H}$, $\mathrm{m}), 2.52-2.60(1 \mathrm{H}, \mathrm{m}), 4.42-4.47(1 \mathrm{H}, \mathrm{m}) ;{ }^{13} \mathrm{C} \mathrm{NMR}\left(\mathrm{CDCl}_{3}\right.$, $125 \mathrm{MHz}) \delta 16.2,21.1,25.6,28.4,33.0,74.4,176.3$.

(2S,5R)-2-Methyl-5-hexanolide (10). ${ }^{25}$ By a procedure similar to that for $\mathbf{l h}$ (Method B), propanal was condensed with (S)-1-amino-2-(methoxymethyl)pyrrolidine to give the corresponding hydrazone. The hydrazone was alkylated with 4-iodo-2-methyl-1-butene, followed by ozonolysis, to give (S)2-methyl-5-oxohexanal, $[\alpha]^{26}{ }_{\mathrm{D}}=-6.7\left(\mathrm{c}=0.6, \mathrm{CHCl}_{3}\right)$. By a procedure similar to that for $\mathbf{2 b}$ (Method E), (S)-2-methyl-5oxohexanal ( $71 \mathrm{mg}, 0.6 \mathrm{mmol}$ ) was treated with $\mathrm{Sml} / 2 / \mathrm{i}-\mathrm{PrSH}$ $(0.3 \mathrm{mmol} / 0.25 \mathrm{mmol})$ at room temperature to give $(2 \mathrm{~S}, 5 \mathrm{R})$ 10 (54 mg, 76\%). Solid, $\mathrm{mp} 40-42{ }^{\circ} \mathrm{C} ;[\alpha]^{21} \mathrm{D}=+63.5(\mathrm{c}=0.2$, $\left.\mathrm{CHCl}_{3}\right)$.

1-Oxa-2-decalone (11a).22 By a procedure similar to that for $\mathbf{2 b}$ (Method E), 3-(2-oxocyd ohexyl)propanal (7a, 79 mg, 0.51 $\mathrm{mmol})$ was treated with $\mathrm{Sml}_{2} / \mathrm{i}-\mathrm{PrSH}(0.25 \mathrm{mmol} / 0.17 \mathrm{mmol})$ at room temperature to give the title compound 11a (trans/ cis =96:4, $55 \mathrm{mg}, 70 \%)$. trans-11a: ${ }^{1} \mathrm{H}$ NMR $\left(\mathrm{CDCl}_{3}, 200 \mathrm{MHz}\right)$ $\delta$ 0.95-2.03 $(11 \mathrm{H}, \mathrm{m}), 2.47-2.61(2 \mathrm{H}, \mathrm{m}), 3.82(1 \mathrm{H}, \mathrm{ddd}, \mathrm{J}$ $=10.2 \mathrm{~Hz}$, J $=10.2 \mathrm{~Hz}$, J $=4.2 \mathrm{~Hz}) / 4.44(\mathrm{br} \mathrm{dd}, \mathrm{J}=6.7,3.3$ $\mathrm{Hz}$ for cis isomer).

1-Oxa-6-tert-butyl-2-decalone (11b). ${ }^{23}$ By a procedure similar to that for $\mathbf{2 b}$ (Method E), 3-(2-oxo-5-tert-butylcyclohexyl)propanal (7b, $160 \mathrm{mg}, 1.2 \mathrm{mmol}$ ) was treated with $\mathrm{Sml}_{2} /$ i-PrSH $(0.50 \mathrm{mmol} / 0.43 \mathrm{mmol})$ at room temperature to give the title compound $\mathbf{1 1 b}$ (141 $\mathrm{mg}, 88 \%$ ) as a mixture of trans and cis isomers (81:19). trans-11b: ${ }^{1} \mathrm{H} \mathrm{NMR}\left(\mathrm{CDCl}_{3}, 300 \mathrm{MHz}\right)$ $\delta 0.84(9 \mathrm{H}, \mathrm{s}), 0.82-1.17(3 \mathrm{H}, \mathrm{m}), 1.40-1.60(3 \mathrm{H}, \mathrm{m}), 1.80-$ $1.87(3 \mathrm{H}, \mathrm{m}), 2.09-2.16(1 \mathrm{H}, \mathrm{m}), 2.51-2.69(2 \mathrm{H}, \mathrm{m}), 3.80$ (1 $\mathrm{H}$, ddd, J $=10.5 \mathrm{~Hz}, \mathrm{~J}=10.4 \mathrm{~Hz}, \mathrm{~J}=4.5 \mathrm{~Hz}$ ). cis-11b: ${ }^{1} \mathrm{H}$ NMR $\left(\mathrm{CDCl}_{3}, 300 \mathrm{MHz}\right) \delta 0.83(9 \mathrm{H}, \mathrm{s}), 1.06-1.33(3 \mathrm{H}, \mathrm{m})$, 1.46-1.61 (4 H, m), 1.81-1.87 (1 H, m), 2.07-2.14 (2 H, m), $2.48(2 \mathrm{H}, \mathrm{t}, \mathrm{J}=7.4 \mathrm{~Hz}), 4.42(1 \mathrm{H}, \mathrm{d}, \mathrm{J}=2.6 \mathrm{~Hz})$.

(1'R,2'S,5'R,5SR)-5-Hydroxy-5-phenylpentanoic acid 2-isopropyl-5-methylcyclohexyl ester (12a). TLC [EtOAC/ hexane (20:80)] $\mathrm{R}_{\mathrm{f}}=0.26$; I R (neat) 3443, $1725 \mathrm{~cm}^{-1}$; ${ }^{1} \mathrm{H}$ NMR $\left(\mathrm{CDCl}_{3}, 300 \mathrm{MHz}\right) \delta 0.71(3 \mathrm{H}, \mathrm{d}, \mathrm{J}=6.9 \mathrm{~Hz}), 0.86(3 \mathrm{H}, \mathrm{d}, \mathrm{J}$
$=6.9 \mathrm{~Hz}), 0.87(3 \mathrm{H}, \mathrm{d}, \mathrm{J}=6.6 \mathrm{~Hz}), 0.93-1.10(1 \mathrm{H}, \mathrm{m}), 1.25-$ $1.52(2 \mathrm{H}, \mathrm{m}), 1.60-1.81(8 \mathrm{H}, \mathrm{m}), 1.89-2.01(2 \mathrm{H}, \mathrm{m}), 2.27-$ $2.31(2 \mathrm{H}, \mathrm{m}), 4.60-4.69(2 \mathrm{H}, \mathrm{m}), 7.20-7.45(5 \mathrm{H}, \mathrm{m}) ;{ }^{13} \mathrm{C} N M R$ $\left(\mathrm{CDCl}_{3}, 75 \mathrm{MHz}\right): \delta 16.1,20.6,21.1,21.9,23.3,26.1,31.1,34.1$, 34.2, 38.2, 40.8, 46.9, 73.8, 73.9, $125.7(2 \times), 127.3,128.3(2 \times)$, 144.5, 173.1; HRMS calcd for $\mathrm{C}_{21} \mathrm{H}_{32} \mathrm{O}_{3}$ : 332.2351. Found: 332.2341.

(1'R,2'S,5'R,5SR)-5-Hydroxy-5-tridecanoic acid 2-isopropyl-5-methylcyclohexyl ester (12e). TLC [EtOAc/hexane (20:80)] $\mathrm{R}_{\mathrm{f}}=0.55$; IR (neat) 3449, $1734 \mathrm{~cm}^{-1} ;{ }^{1} \mathrm{H} N M R$ $\left(\mathrm{CDCl}_{3}, 400 \mathrm{MHz}\right) \delta 0.73(3 \mathrm{H}, \mathrm{d}, \mathrm{J}=6.9 \mathrm{~Hz}), 0.83-1.11(12$ $\mathrm{H}, \mathrm{m}), 1.24-2.11(25 \mathrm{H}, \mathrm{m}), 2.29(2 \mathrm{H}, \mathrm{dt}, \mathrm{J}=7.4,1.9 \mathrm{~Hz})$, $3.52-3.59(1 \mathrm{H}, \mathrm{m}), 4.66(1 \mathrm{H}, \mathrm{ddd}, \mathrm{J}=10.8,10.8,4.3 \mathrm{~Hz}) ;{ }^{13} \mathrm{C}$ $\mathrm{NMR}\left(\mathrm{CDCl}_{3}, 100 \mathrm{MHz}\right): \delta 14.1\left(\mathrm{CH}_{3}\right), 16.3\left(\mathrm{CH}_{3}\right), 20.7\left(\mathrm{CH}_{3}\right)$, $21.1\left(\mathrm{CH}_{2}\right), 22.0\left(\mathrm{CH}_{3}\right), 22.6\left(\mathrm{CH}_{2}\right), 23.4\left(\mathrm{CH}_{2}\right), 25.6\left(\mathrm{CH}_{2}\right), 26.3$ $(\mathrm{CH}), 29.3\left(\mathrm{CH}_{2}\right), 29.6\left(\mathrm{CH}_{2}\right), 29.7\left(\mathrm{CH}_{2}\right), 31.7(\mathrm{CH}), 31.9\left(\mathrm{CH}_{2}\right)$, 34.3 $\left(\mathrm{CH}_{2}\right), 34.5\left(\mathrm{CH}_{2}\right), 36.7\left(\mathrm{CH}_{2}\right), 37.5\left(\mathrm{CH}_{2}\right), 40.9\left(\mathrm{CH}_{2}\right), 47.0$ $\left(\mathrm{CH}_{2}\right), 71.4(\mathrm{CH}), 74.1(\mathrm{CH}), 173.3(\mathrm{C})$; HR-FAB-MS calcd for $\mathrm{C}_{23} \mathrm{H}_{45} \mathrm{O}_{3}\left(\mathrm{M}^{+}+1\right)$ : 369.3369. Found: 369.3362 .

(2S,2'S,4S,4'S,5R, 5'R )-N,N' -B is(3,4-di methyl-2-oxo-5phenyl-1,3,2-oxazaphospholan-2-yl)-ethane-1,2-diamine (15).33 According to the known procedure, the chiral phosphorus(V) reagent $\mathbf{1 5}$ was prepared from (1R,2S)-(-)ephedrine hydrochloric salt by subsequent treatments with $\mathrm{POCl}_{3} / \mathrm{Et}_{3} \mathrm{~N}$ and ethylenediamine.

Salen 16. By a procedure similar to that for the related salen compounds, ${ }^{34}$ the chiral salen reagent 16 was prepared by condensation of $(1 R, 2 R)-(-)-1,2$-cyclohexanediamine with 4-azi domethyl-2-hydroxybenzal dehyde.

(1S,2S,5R)-2-I sopropyl-5-methyl-cyclohexanethiol (17). . $^{35}$ Treatment of $(-)$-menthol $(3.12 \mathrm{~g}, 20 \mathrm{mmol})$ with p-toluenesulfonyl chloride $(7.70 \mathrm{~g}, 40 \mathrm{mmol})$ in pyridine $(30 \mathrm{~mL})$ at room temperature for $16 \mathrm{~h}$ gave the corresponding tosylate $(6.05 \mathrm{~g}$, $97 \%)$. The tosylate $(2.60 \mathrm{~g}, 8.4 \mathrm{mmol})$ was heated $\left(50-60{ }^{\circ} \mathrm{C}\right)$ with potassium thioacetate (AcSK, $2.80 \mathrm{~g}, 25 \mathrm{mmol}$ ) in $\mathrm{Me}_{2}$ SO $(17 \mathrm{~mL})$ for $36 \mathrm{~h}$. The mixture was cooled and extracted with $\mathrm{CHCl}_{3}(5 \times 15 \mathrm{~mL})$. The organic phase was dried $\left(\mathrm{Na}_{2}-\right.$ $\left.\mathrm{SO}_{4}\right)$, concentrated, and distilled $\left(80{ }^{\circ} \mathrm{C}, 0.05 \mathrm{mmHg}\right.$ ) to give (1S)-neomenthyl acetate (1.31 g, 73\%). Diisobutylaluminum hydride (DIBAL , $6 \mathrm{mmol}$, $1 \mathrm{M}$ solution in $\mathrm{CH}_{2} \mathrm{Cl}_{2}$ ) was added dropwise to a $\mathrm{CH}_{2} \mathrm{Cl}_{2}$ solution (20 mL) of (1S)-neomenthyl acetate $(420 \mathrm{mg}, 1.96 \mathrm{mmol})$ at $0{ }^{\circ} \mathrm{C}$. The mixture was stirred for $5 \mathrm{~h}$ and quenched by addition of saturated $\mathrm{NH}_{4} \mathrm{Cl}$. Water $(40 \mathrm{~mL})$ and $1 \mathrm{M} \mathrm{HCl}(20 \mathrm{~mL})$ were added, and the mixture was extracted with $\mathrm{Et}_{2} \mathrm{O}(4 \times 30 \mathrm{~mL})$. The organic phase was washed with brine, dried $\left(\mathrm{Na}_{2} \mathrm{SO}_{4}\right)$, concentrated, and distilled $\left(90{ }^{\circ} \mathrm{C}, 9 \mathrm{mmHg}\right.$ ) to give the title compound $\mathbf{1 7}$ (330 mg, 98\%). $[\alpha]^{25}+53.6\left(\mathrm{c}=3.1, \mathrm{CHCl}_{3}\right)$.

(1S,2S,3R,5R)-3-Pinanethiol (18). ${ }^{37}$ By a procedure similar to that for 17, (+)-isopinocampheol was activated as the mesylate, which was subsequently treated with AcSK and DIBAL to give the title compound 18. $[\alpha]^{25}{ }_{D}=-5.7(c=3.7$, $\left.\mathrm{CHCl}_{3}\right)$.

(3R)-Cholestanethiol (19). ${ }^{38}$ A THF solution ( $5 \mathrm{~mL}$ ) of $3 \beta$ chloesterol $(772 \mathrm{mg}, 2.0 \mathrm{mmol}$ ) was treated with a mixture of $\mathrm{Ph}_{3} \mathrm{P}$ (630 mmol, $2.4 \mathrm{mmol}$ ) and diisopropyl diazocarbodiimide (DIAD, $485 \mathrm{mg}, 2.4 \mathrm{mmol})$ in THF (15 mL) at $0{ }^{\circ} \mathrm{C}$ for $2 \mathrm{~h}$ to give the corresponding thi oacetate (590 mg, 78\%). Reduction of the thioacetate (138 mg, $0.3 \mathrm{mmol})$ with $\mathrm{LiAlH}_{4}(120 \mathrm{mg}$, $3.0 \mathrm{mmol})$ in $\mathrm{Et}_{2} \mathrm{O}(10 \mathrm{~mL})$ for $30 \mathrm{~min}$ gave the title compound 19 (122 mg, 99\%). Solid, 80-82 ${ }^{\circ} \mathrm{C}$.

(1S,2R,4R)-(-)-10-Mercaptoisoboneol (20).39 Treatment of (1S)-(+)-camphorsulfonic acid (1.16 g, $5 \mathrm{mmol}$ ) with $\mathrm{SOCl}_{2}$ gave the corresponding sulfonyl chloride, which was reduced with $\mathrm{LiAlH}_{4}$ to give the title compound $\mathbf{2 0}$ ( $37 \%$ overall yield)

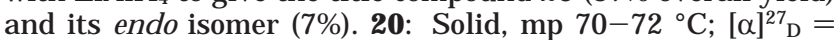
-56.1 ( $\mathrm{c}=1.1, \mathrm{CHCl}_{3}$ ).

(S)-(+)-2-( $\alpha$-Mercapto- $\alpha$-phenylbenzyl)-1-methylpyrrolidine (26). ${ }^{41}$ According to the known procedure, ${ }^{41}$ (S)proline-N-benzyl carbamate was subjected to a sequence of esterification, addition with $\mathrm{PhMgBr}$, reduction with $\mathrm{LiAlH}_{4}$ and substitution with Lawesson reagent to give the title compound 26 in $32 \%$ overall yield. $[\alpha]^{25}{ }_{D}=+249.5$ (c $=1.0$, $\mathrm{CHCl}_{3}$ ). 
(1R,2S)-(-)-1-Phenyl-2-piperidyl-1-propanethiol (27).42b $(1 \mathrm{R}, 2 \mathrm{~S})-(-)-\mathrm{N}$ orephedrine $(2.3 \mathrm{~g}, 10 \mathrm{mmol})$ was al kylated with 1,5-dibromopentane, followed by activation to the corresponding mesylate. The mesylate was treated with AcSK, followed by reduction with DIBAL, to give the title compound $\mathbf{2 7}$ in $42 \%$ overall yield. $[\alpha]^{27}-64.2\left(\mathrm{c}=1.2, \mathrm{CHCl}_{3}\right.$ ).

(1R,2S)-2-Dibenzylamino-1-phenyl-1-propanethiol (28). (1R,2S)-(-)-Norephedrine $(2.3 \mathrm{~g}, 10 \mathrm{mmol})$ was subjected to reductive alkylation with $\mathrm{PhCHO} / \mathrm{NaBH}_{3} \mathrm{CN}$ (two repeated processes) to give (1R,2S)-N,N-dibenzylamino-1-phenylpropanol, which was activated as a mesylate. The mesylate was treated with AcSK, followed by saponification $(\mathrm{KOH}$ in aqueous $\mathrm{MeOH}$ ), to give the title compound $\mathbf{2 8}$ in $39 \%$ overall yield. $[\alpha]^{28}-101.1\left(\mathrm{c}=1.4, \mathrm{CHCl}_{3}\right)$.

(1R,2S)-1-Phenyl-2-(N-methylethylamino)-1-propanethiol (29) and (1R,2S)-1-Phenyl-2-(N-methylacetamido)1-propanethiol (33). ${ }^{42 a}(1 \mathrm{R}, 2 \mathrm{~S})-(-)$-E phedrine $(4.02 \mathrm{~g}, 20$ mmol) was treated with $\mathrm{Ph}_{3} \mathrm{P}(1.1 \mathrm{~g}, 4 \mathrm{mmol}), \mathrm{Et}_{3} \mathrm{~N}(8 \mathrm{~mL})$ and diethyl azodicarbodiimide (DE AD, $6.9 \mathrm{~g}, 40 \mathrm{mmol}$ ) in THF $(60 \mathrm{~mL})$ at room temperature for $10 \mathrm{~h}$. After the solids were filtered, the filtrate was concentrated and distilled $\left(70^{\circ} \mathrm{C}, 0.5\right.$ $\mathrm{mmHg}$ ) to give (2S,3S)-1,2-dimethyl-3-phenylaziridine (2.53 $\mathrm{g}, 89 \%)$. The aziridine $(1.41 \mathrm{~g}, 9.9 \mathrm{mmol})$ was treated with ACSK $(1.51 \mathrm{~g}, 19.9 \mathrm{mmol})$ in $\mathrm{CH}_{2} \mathrm{Cl}_{2}(20 \mathrm{~mL})$ at $0{ }^{\circ} \mathrm{C}$ for $2 \mathrm{~h}$ to give compound 33 (2.09, 95\%), via the ring opening reaction and transesterification. Reduction of $\mathbf{3 3}(299 \mathrm{mg}, 1.3 \mathrm{mmol})$ with $\mathrm{LiAlH}_{4}(120 \mathrm{mg}, 3.0 \mathrm{mmol})$ in refluxing THF $(20 \mathrm{~mL})$ for 5 h gave compound 29 (178 mg, 64\%). 29: $[\alpha]^{29} \mathrm{D}=-224.7$ ( $\mathrm{c}$ $=2.5, \mathrm{CHCl}_{3}$ ). 33: $[\alpha]^{25} \mathrm{D}-93.4\left(\mathrm{c}=1.96, \mathrm{CH}_{2} \mathrm{Cl}_{2}\right.$ ).

(1R,2S)-2-Acetamido-1-phenyl-1-propanethiol (30). (1R, $2 \mathrm{~S})-(-)$-N orephedrine $\left(1.51 \mathrm{~g}, 10 \mathrm{mmol}\right.$ ) was treated with $\mathrm{Ph}_{3} \mathrm{P}$ $(3.2 \mathrm{~g}, 12 \mathrm{mmol})$ and DIAD $(2.2 \mathrm{~g}, 11 \mathrm{mmol})$, by procedure similar to that for 33, to give (2S,3S)-2-methyl-3-phenylaziridine $(1.15 \mathrm{~g}, 86 \%)$. The aziridine $(259 \mathrm{mg}, 1.9 \mathrm{mmol})$ was treated with thioacetic acid (500 mg, $6.5 \mathrm{mmol}$ ) in $\mathrm{CH}_{2} \mathrm{Cl}_{2}$ at $0{ }^{\circ} \mathrm{C}$ for $2 \mathrm{~h}$ to give the title compound $\mathbf{3 0}$ (350 mg, 86\%). Solid, $\mathrm{mp} 78-80{ }^{\circ} \mathrm{C}$; TLC [EtOAc/hexane (1:1)] $\mathrm{R}_{\mathrm{f}}=0.26 ;[\alpha]^{29}{ }_{\mathrm{D}}=$ -67.3 (c = 0.9, $\mathrm{CHCl}_{3}$ ); IR (neat) 3285, 1650, $1554 \mathrm{~cm}^{-1} ;{ }^{1} \mathrm{H}$ NMR $\left(\mathrm{CDCl}_{3}, 300 \mathrm{MHz}\right) \delta 1.04(3 \mathrm{H}, \mathrm{d}, \mathrm{J}=6.6 \mathrm{~Hz}), 1.85(1 \mathrm{H}$, $\mathrm{d}, \mathrm{J}=7.3 \mathrm{~Hz}, \mathrm{SH}), 1.92(3 \mathrm{H}, \mathrm{s}), 4.29(1 \mathrm{H}, \mathrm{dd}, \mathrm{J}=7.3,5.0$ $\mathrm{Hz})$, 4.34-4.45 (1 H, m), 5.71 (1 H, br s), 7.20-7.39 (5 H, m); ${ }^{13} \mathrm{C} \mathrm{NMR}\left(\mathrm{CDCl}_{3}, 75 \mathrm{MHz}\right) \delta 15.9\left(\mathrm{CH}_{3}\right), 23.4\left(\mathrm{CH}_{3}\right), 49.1(\mathrm{CH})$, $50.2(\mathrm{CH}), 127.4(\mathrm{CH}), 127.8(\mathrm{CH} \times 2), 128.4(\mathrm{CH} \times 2), 140.5$ (C), $169.3(\mathrm{C}=\mathrm{O})$. HR-FAB-MS calcd for $\mathrm{C}_{11} \mathrm{H}_{16} \mathrm{NOS}\left(\mathrm{M}^{+}+1\right)$ : 210.0953. Found: 210.0960.

(1R,2S)-2-Benzamido-1-phenyl-1-propanethiol (31). By a procedure similar to that for $\mathbf{3 0}$, the aziridine derived from (1R,2S)-(-)-norephedrine (164 mg, $1.2 \mathrm{mmol}$ ) was treated with thiobenzoic acid ( $255 \mathrm{mg}, 6.5 \mathrm{mmol}$ ) to give the title compound 31 (331 mg, 99\%). Solid, mp $145-146{ }^{\circ} \mathrm{C} ;[\alpha]^{29} \mathrm{D}-51.1$ (c $=$ $\left.1.90, \mathrm{CHCl}_{3}\right)$.

(1R,2S)-1-Phenyl-2-(4-toluenesulfonamido)-1-propanethiol (32). (1R,2S)-(-)-Norephedrine was treated with p-toluenesulfonyl chloride to give the corresponding sulfonamide. By a procedure similar to that for $\mathbf{2 8}$, the sulfonamide was converted to the title compounds 32 in $69 \%$ yield, via substitution of the mesylate with AcSK and saponification. Solid, mp 89-90 ${ }^{\circ} \mathrm{C} ;[\alpha]^{24} \mathrm{D}-35.0\left(\mathrm{c}=1.0, \mathrm{CHCl}_{3}\right)$.

(1R,2S)-2-(N-Benzylacetamido)-1-phenyl-1-propanethiol (34). (1R,2S)-(-)-Norephedrine was subjected to reductive alkylation with $\mathrm{PhCHO} / \mathrm{NaBH}_{3} \mathrm{CN}$ to give (1R,2S)-2benzylamino-1-phenylpropanol (70\% yield), which was converted to the corresponding aziridine (64\% yield) by treatment with $\mathrm{Ph}_{3} \mathrm{P} / \mathrm{CCl}_{4}$ in $\mathrm{CH}_{3} \mathrm{CN}$ solution at room temperature for $18 \mathrm{~h}$. The aziridine $(228 \mathrm{mg}, 1.0 \mathrm{mmol}$ ) was treated with thioacetic acid, by a procedure similar to that for 30 , to give the title compound 34 (262 mg, 88\%). Solid, mp 92-94 ${ }^{\circ} \mathrm{C}$; $[\alpha]^{25}-25.3\left(\mathrm{C}=2.1, \mathrm{CHCl}_{3}\right)$.

(1R,2S)-2-(N-Methylbenzamido)-1-phenyl-1-propanethiol (35). By a procedure similar to that for 31, (2S,3S)-1,2dimethyl-3-phenylaziridine (626 $\mathrm{mg}, 4.2 \mathrm{mmol}$ ) was treated with thiobenzoic acid acid (740 $\mathrm{mg}, 5.3 \mathrm{mmol}$ ) to give the title compound 35 (1.19 g, 99\%). $[\alpha]^{25}-22.5$ (c = 1.25, $\mathrm{CH}_{2} \mathrm{Cl}_{2}$ ).

(1R,2R)-2-(N-Methylacetamido)-1-phenyl-1-propanethiol (36). By a procedure similar to that for 30 , (1R,2R)$(-)$-pseudoephedrine $\left(1.65 \mathrm{~g}, 10 \mathrm{mmol}\right.$ ) was treated with $\mathrm{Ph}_{3} \mathrm{P}$ and DIAD to give the corresponding aziridine (1.24 g, 84\%). The aziridine ( $139 \mathrm{mg}, 0.94 \mathrm{mmol}$ ) was treated with thioacetic acid to give the title compound 36 (169 mg, 80\%). Solid, mp 95-97 ${ }^{\circ} \mathrm{C} ;[\alpha]^{27} \mathrm{D}-195.0\left(\mathrm{C}=1.0, \mathrm{CHCl}_{3}\right)$.

(1S,2R)-2-Acetamido-1,2-diphenyl-1-ethanethiol (37). By a procedure similar to that for $30,(1 S, 2 R)-(+)-2$-amino1,2-diphenylethanol (587 mg, $2.8 \mathrm{mmol}$ ) was treated with $\mathrm{Ph}_{3} \mathrm{P}$ and DIAD to give the corresponding aziridine ( $496 \mathrm{mg}, 93 \%$ ). The aziridine ( $333 \mathrm{mg}, 1.7 \mathrm{mmol}$ ) was treated with thioacetic acid to give the title compound $\mathbf{3 7}$ (519 $\mathrm{mg}, 66 \%)$. Solid, $\mathrm{mp}$ $189-190{ }^{\circ} \mathrm{C} ;[\alpha]^{27} \mathrm{D}=-70.2\left(\mathrm{c}=1.0, \mathrm{DMSO}^{2} \mathrm{~d}_{6}\right)$

(1S,2R)-2-(N-Benzylacetamido)-1,2-diphenyl-1-ethanethiol (38). By a procedure similar to that for 34, (1S,2R)-(+)2-amino-1,2-diphenylethanol was sequentially treated with $\mathrm{PhCHO} / \mathrm{NaBH}_{3} \mathrm{CN}, \mathrm{Ph}_{3} \mathrm{P} / \mathrm{DI} \mathrm{AD}$, and thioacetic acid to give the title compound 38 in $48 \%$ overall yield. $[\alpha]^{27}{ }_{D}=-82.3(\mathrm{C}=$ 1.2, $\mathrm{CHCl}_{3}$ ).

Acknowledgment. We thank the National Science Council for financial support, Professor T. -K. Yang (National Chung-Hsing University) for providing us the samples of compounds 20-24, and Professor C.-T. Chen (National Taiwan University) for helpful discussion.

Supporting Information Available: Additional experimental procedures, spectral data, and ${ }^{1} \mathrm{H}$ and ${ }^{13} \mathrm{C}$ spectra of some selected compounds, as well as the crystal data, bond distances, bond angles, and ORTEP drawing of compound 30. This material is available free of charge via the Internet at http://pubs.acs.org.

\section{] O016058T}

